Board of Governors of the Federal Reserve System

\author{
International Finance Discussion Papers \\ Number 850 \\ January 2006
}

The Adjustment of Global External Imbalances:

Does Partial Exchange Rate Pass-Through to Trade Prices Matter?

Christopher Gust

Nathan Sheets

NOTE: International Finance Discussion Papers are preliminary materials circulated to stimulate discussion and critical comment. References in publications to International Finance Discussion Papers (other than an acknowledgement that the writer has had access to unpublished material) should be cleared with the author or authors. Recent IFDPs are available on the Web at www.federalreserve.gov/pubs/ifdp/. This paper can be downloaded without charge from Social Science Research Network electronic library at http://www.ssrn.com/. 


\title{
The Adjustment of Global External Balances: Does Partial Exchange Rate Pass-Through to Trade Prices Matter?*
}

\author{
Christopher Gust and Nathan Sheets ${ }^{\dagger}$
}

Federal Reserve Board

January 2006

\begin{abstract}
Recent papers have found evidence of a decline in exchange rate pass-through to import prices in the United States and in a number of other industrial countries as well. This paper examines the implications of a decline in pass-through for the prospective adjustment of global external imbalances. We find that a decline in pass-through to trade prices may mute the responsiveness of the nominal trade balance to shifts in the exchange rate, but that a decline in pass-through does not shut down nominal adjustment completely. We also find that the channels of adjustment vary with pass-through. When pass-through is high, nominal adjustment is driven by moves in trade quantities. When pass-through is low, nominal adjustment mainly reflects shifts in the terms of trade (i.e., export prices relative to import prices). Our work employs a forward-looking, optimizing model in which firms set their prices with an eye toward maintaining their competitiveness against other producers; this feature of the model generates a variable desired markup and, hence, exchange rate pass-through that is less than complete.
\end{abstract}

Keywords: Import prices, Export prices, Trade balance, DGE model

JEL classification: F3, F41

*The authors thank Chris Erceg, Joseph Gagnon, Dale Henderson, Karen Johnson, Steven Kamin, and Trevor Reeve for useful comments and suggestions. The views expressed in this paper are solely the responsibility of the authors and should not be interpreted as reflecting the views of the Board of Governors of the Federal Reserve System or of any other person associated with the Federal Reserve System.

${ }^{\dagger}$ Email addresses: christopher.j.gust@frb.gov and nathan.sheets@frb.gov. 


\section{Introduction and Summary}

Much of the previous work examining changes in exchange rate pass-through to trade prices has emphasized the implications for domestic inflation. In this paper, we examine a second channel through which a shift in pass-through might affect economic performance at home and abroad - that is, by influencing the features of global external adjustment.

Our work considers how changes in pass-through affect the trade balance both when other variables - namely, domestic and foreign activity - are held constant (partial-equilibrium effects) and when these variables are allowed to vary (general-equilibrium effects). We emphasize the case in which trade-price elasticities are roughly unity (in accordance with our interpretation of the data), but we consider other cases as well. We focus particularly on the nominal trade balance, since for reasons outlined below we see this as the central barometer of external adjustment. The following bullets summarize our findings.

\section{Partial-Equilibrium Effects:}

- When trade-price elasticities are near unity, a one-percent depreciation of the exchange rate improves the trade balance by roughly one percent of the value of exports, regardless of the extent of pass-through.

- Spending on imports is unchanged; any rise in import prices is exactly offset by a decline in import volumes.

- Export revenues rise by one percent. Foreign spending on home exports is unchanged in foreign-currency terms, but the value of these expenditures expressed in the home currency increases. If import price pass-through abroad is zero, all of this increase comes from a rise in home-currency denominated export prices (with quantities unchanged); if pass-through is complete, all of it comes from a rise in export volumes (with home-currency export prices unchanged).

- If the price elasticities of import and export demand are greater than one, a decline in passthrough results in less improvement of the nominal trade balance following a depreciation 
of the exchange rate. The decline in pass-through tends to mute the response of trade quantities more than it does the response of trade prices. Conversely, if the trade-price elasticities are less than one, a decline in import price pass-through facilitates adjustment.

General-Equilibrium Effects:

- In our general equilibrium analysis, we assume that the initial move in the exchange rate is driven by a change in the risk premium on home assets and that monetary policy follows a Taylor rule at home and abroad.

- A decline in pass-through tends to mute the sensitivity of the real economy to a change in the exchange rate, damping the general-equilibrium feedback effects that attend the exchange rate move and, thus, attenuating the adjustment of the nominal trade balance. However, even if the general-equilibrium effects are muted entirely, the channels of adjustment identified in the partial-equilibrium analysis are still operative.

- The magnitude of the general-equilibrium feedback effects also depends on a variety of other features of the home and foreign economies, including the sensitivity of inflation to moves in trade prices, the aggressiveness of the monetary policy response, and the sensitivity of import demand to shifts in domestic activity.

The remainder of our paper is organized as follows. The next two sections provide a brief literature review and sketch out three scenarios that highlight the potential effects on the trade balance of varying degrees of exchange rate pass-through. The following section simulates the three scenarios using a general equilibrium macro model - a modified version of SIGMA that we call "SIGMA-PT." ${ }^{1}$ This version of the model allows firms to set their prices with an eye toward maintaining competitiveness against other producers; this results in a variable desired markup and in exchange rate pass-through that is less than complete. The final section of the paper draws some conclusions. We supplement the main text with two appendices.

\footnotetext{
${ }^{1}$ For a detailed description of the features of SIGMA, see Erceg, Guerrieri, and Gust (2005).
} 
The first fleshes out the partial-equilibrium relationship between exchange rate pass-through and external adjustment, while the second provides a formal discussion of the features and calibration of SIGMA-PT.

\section{A Review of the Literature and Some Key Issues}

As background for this discussion, we provide a brief review of recent empirical evidence regarding the evolution of the exchange rate sensitivity of trade prices. Marazzi, Sheets, Vigfusson, et al. (2005) have found evidence of a sustained decline in the exchange rate sensitivity of U.S. "core" import prices (i.e., excluding computers, semiconductors, and oil), from above 0.5 in the 1970s and 1980s to roughly 0.2 during the past decade. In other words, a 10 percent depreciation of the dollar was typically associated with a rise in core import prices of more than 5 percent during the 1970s and 1980s but of only around 2 percent through the past decade. Recent analyses by the BIS and the IMF have found broadly similar results. ${ }^{2}$ Work by Campa and Goldberg (2004) does not find a decline in exchange rate pass-through to U.S. import prices, but these authors nevertheless conclude that pass-through to U.S. import prices is "quite low."

There is also a growing body of work on the evolution of import price pass-through in other industrial countries. For example, Marazzi, Sheets, Vigfusson, et al. (2005) find that pass-through to import prices has fallen significantly in recent years in Japan and has been low and stable in Germany. ${ }^{3}$ Research by the BIS (2005), Ihrig, Marazzi, and Rothenberg (2005), and Sekine (2005) has detected declines for the G-7 countries (albeit sometimes small declines) in the 1990-2004 period relative to the previous decades. The decline in import price passthrough does not appear to be a universal phenomenon, however. For some smaller industrial countries - including, for example, Australia and Sweden - there is evidence that pass-through to import prices has remained close to one. ${ }^{4}$ As far as we know, no broad studies of import

\footnotetext{
${ }^{2}$ See BIS Annual Report (2005), Sekine (2005), and IMF Selected Issues (2005).

${ }^{3}$ These results for Japan are broadly consistent with those reported by Otani, Shiratsuka, and Shirota (2003).

${ }^{4}$ For Australia, see Ellis (2004) and Heath, et al. (2004); for Sweden, see Nessen (2004) and Adolfson (2004).
} 
price pass-through for the emerging market or developing countries have been done, presumably because of data limitations. ${ }^{5}$

If import prices across the globe are on average becoming less sensitive to the exchange rate, then it follows that export prices across the globe (denominated in exporters' home currencies) are on average becoming more sensitive to the exchange rate. When an exporting firm holds its foreign-currency price essentially constant in the face of exchange rate moves (which is the case when import price pass-through is low), the price in the firm's domestic currency must move roughly one-for-one with the exchange rate. In other words, a decline in import price pass-through suggests that exporters are increasingly absorbing exchange rate shocks into their domestic-currency margins, rather than changing their foreign-currency prices.

Recent empirical work provides some evidence that this has, in fact, occurred. Marazzi, Sheets, Vigfusson, et al. (2005) find that the export prices charged by the Asian NIEs (Hong Kong, Korea, Singapore, and Taiwan) have shown significantly more sensitivity to exchange rate moves during the past decade than during the previous decade. The sensitivity of Canadian export prices to the exchange rate also appears to have stepped up during the past decade. U.S. export prices, in contrast, have shown little evidence of increased exchange rate sensitivity in recent years.

We conclude this section with the following observation. Throughout this paper, we discuss two notions of external adjustment - the first we call "real adjustment" and the second we call "nominal adjustment." Real adjustment entails shifts in the relative quantities of imports and exports or, equivalently, moves in real net exports. The second concept focuses on adjustment of nominal trade flows as summarized by the nominal trade balance. Notably, considerations of long-term sustainability put bounds on the ratio of the nominal trade deficit to GDP over the medium to long term, ${ }^{6}$ but no similar bounds are placed on the behavior of

\footnotetext{
${ }^{5}$ Working with a panel of over 70 countries, Frankel, Parsley, and Wei (2005) focus on the prices of eight narrowly defined imported goods. Somewhat surprisingly, they find that for these goods exchange rate passthrough to unit import values at the dock actually increased during the 1990s.

${ }^{6}$ Specifically, assuming that in the long run the rate of return on U.S. external debt is close to the economy's long run rate of growth, stabilization of the debt-to-GDP ratio (a necessary condition for external sustainability) requires the nominal trade balance on goods and services (plus net transfer payments) to eventually be in the neighborhood of zero.
} 
real quantities. As such, adjustment of the nominal trade balance is the central, indispensable feature of external adjustment. This improvement in the nominal balance can be achieved either by a move in trade prices (a terms of trade improvement) or by a shift in real quantities.

\section{Three Benchmark Scenarios}

We study a world in which there are two equal-sized countries - home and foreign. This framework usefully highlights the issues of interest and streamlines the analysis. The discussion focuses on three benchmark scenarios:

Scenario 1: High import price pass-through in the home and foreign countries. In this case, both domestic and foreign import prices (denominated in the local currencies of the importing countries) are very sensitive to the exchange rate. As noted above, an implication of this is that the prices charged by exporting firms (denominated in the local currencies of the exporting countries) are insensitive to moves in the exchange rate.

Scenario 2: Low import price pass-through in the home and foreign countries. In this instance, domestic and foreign import prices (in local-currency terms) show little sensitivity to the exchange rate. Export prices, in contrast, are very sensitive to the exchange rate.

Scenario 3: Low import price pass-through in the home country and high import price pass-through in the foreign country. ${ }^{7}$ In this scenario, the home country and the foreign country are no longer symmetric. Import prices in the home country do not respond to the exchange rate, while those abroad are very responsive. The implication is that home exporters hold their domestic-currency prices fixed as the exchange rate moves, but foreign exporters shift their domestic-currency prices in response to exchange rate changes. This scenario corresponds to a world in which trade prices are set in the home country and are translated abroad by movements in the exchange rate.

In the simulations that follow, the two countries are identical, with the exception of the asymmetry in Scenario 3. We have set each country's import and export shares at 12.5 percent,

\footnotetext{
${ }^{7}$ We do not consider the case in which there is high import price pass-through in the home country and low import price pass-through in the foreign country, since this would just be the mirror image of Scenario 3 .
} 
and the long-run price elasticities for imports and exports are both near unity. This value for the trade-price elasticities is consistent with our forecasting models and with our interpretation of the empirical evidence. ${ }^{8}$ Nevertheless, we have also run the simulations with other tradeprice elasticities, and will discuss how the results differ in such cases. Monetary policy in both countries is assumed to follow a Taylor rule.

While all three of these scenarios are useful benchmarks, it is helpful to make a few comments about their empirical relevance for the United States. The evidence discussed in the previous section strongly suggests that pass-through to U.S. import prices is now relatively low, which differs significantly from the features of Scenario 1. As noted above, the results for foreign import price pass-through are less conclusive. The evidence suggests that import prices pass-through for some major countries (e.g., Japan and Germany) is also low; but for some smaller countries (e.g., Australia and Sweden), pass-through to import prices appears to have remained high. As such, the global economy at present appears to have features of both Scenario 2 and Scenario 3.

\section{Model Simulations}

Features of the model. We simulate these three scenarios in a DGE model that we call "SIGMAPT." In our model, exchange rate pass-through to import and export prices is incomplete for two reasons. First, as in SIGMA, prices are sticky in local currencies. This gives rise to partial exchange rate pass-through in the short run, but - in the medium to long run-prices adjust and pass-through rises. ${ }^{9}$ Second, an important feature of SIGMA-PT, which has not yet been incorporated into SIGMA, is that firms set their prices with an eye toward maintaining their competitiveness against other home and foreign producers. This results in a variable desired markup that tends to mute price increases following shocks - such as an exchange rate appreciation - that would otherwise cause exporting firms to raise their prices above those of

\footnotetext{
${ }^{8}$ See, for example, Hooper and Marquez (1995), Senhadji and Montenegro (1999), and Marquez (2002).

${ }^{9}$ In the scenarios with incomplete import price pass-through, the parameter governing export price adjustment is consistent with contracts lasting for two quarters subject to lagged indexation. In contrast, the price adjustment parameter governing domestic prices and wages is consistent with four-quarter contracts.
} 
their competitors. ${ }^{10}$ This characteristic of the desired markup gives rise to incomplete passthrough, even in the medium to long run.

More generally, SIGMA-PT has most of the important features of SIGMA, including sticky wages and prices, habit persistence in consumption, segmented markets (which give rise to price discrimination between the home and foreign markets), and adjustment costs for imports (which allow for a lower trade-price elasticity in the short run than in the long run); however, SIGMA-PT does not have endogenous capital investment and non-Ricardian, "rule of thumb" households. As in SIGMA, imports depend on domestic demand (consumption in our version of the model) rather than on real output. Appendix B provides a formal description of the properties of SIGMA-PT.

As we outline the features of our simulations below, we emphasize those results that are likely to arise in a broad set of macro models, rather than those that may depend on the particular calibration of SIGMA-PT. As such, we focus more on the qualitative features of the simulations than on the particular quantitative responses to the assumed shocks.

Simulation Results. We now use SIGMA-PT to simulate our benchmark scenarios. We consider a shock to the risk premium on home assets. The shock is assumed to be quite persistent, with its effects on the real exchange rate dying out only slowly over time. The shock is identical in each of the three cases, but, as shown in the upper-left panel of Figure 1, the exchange rate initially depreciates by somewhat less than 10 percent in Scenario 1 (when import price pass-through at home and abroad is high), by somewhat more than 10 percent in Scenario 2 (when import price pass-through at home and abroad is low), and by exactly 10 percent in Scenario 3 (when import price pass-through is low at home but high abroad). These contrasting outcomes reflect the fact that the underlying structure of the home and foreign economies differs across the three scenarios. With higher pass-through, the depreciation of the

\footnotetext{
${ }^{10}$ We use the term "desired" markup since this is the markup a firm would choose optimally in the absence of the sticky prices, while the actual markup in the model also takes into account the sticky-price assumption. We model the desired markup using a demand curve with a non-constant elasticity as in Kimball (1995) and Gust, Leduc, and Vigfusson (2005). Our three scenarios change the degree of pass-through by varying the parameters of the demand curve. Gust, Leduc, and Vigfusson (2005) show that pass-through also depends on the level of technology and trade costs and argue that increased trade integration helps explain the observed decline in import price pass-through in industrial countries.
} 
home currency puts greater upward pressure on domestic prices and output and, accordingly, leads to larger rises in domestic interest rates; by the same token, when pass-through abroad is high, interest rates there fall by more. For these reasons, the decline in the exchange rate in response to a risk-premium shock is largest when pass-through is low in both countries and smallest when pass-through is high in both countries. ${ }^{11}$

Following the initial risk premium shock, the real exchange rate depreciates somewhat further in Scenario 1 and Scenario 3, as - after an up-front tightening of policy-interest rates are eased back to baseline. In Scenario 2, the real exchange rate begins to strengthen after five quarters, with the relatively modest expected easing of policy in this case failing to offset the decaying effects of the risk premium shock.

In Scenario 1, home import prices are relatively sensitive to the exchange rate and, hence, consumer prices (not shown) and output post comparatively large rises. This elicits a more aggressive monetary policy response, which results in a higher real interest rate than in the other two cases. The higher real interest rate, in turn, brings output back toward baseline, as the compression of domestic demand (consumption) offsets rising net exports. In the other two cases, where import price pass-through is low, the effects are qualitatively similar but much smaller in magnitude.

We turn now to the behavior of the external sector. As shown in the upper-left panel of Figure 2, in the case where home import price pass-through is high (Scenario 1), the import price relative to the domestic output price jumps up, closely tracking the exchange rate (as foreign exporters maintain their domestic-currency prices). ${ }^{12}$ For the other two scenarios, moves in the relative import price are more subdued, consistent with lower pass-through. As seen in the upper-right panel, real imports fall markedly in the high pass-through case, in response to the

\footnotetext{
${ }^{11}$ A related observation is that-holding the magnitude of risk premium shocks constant-a decline in exchange rate pass-through tends to increase the volatility of the exchange rate. See Bergin and Feenstra (2001) for a discussion of this issue.

${ }^{12}$ Throughout this section we consider the behavior of trade prices relative to the price of domestic and foreign output. We do this to abstract from trends in absolute price levels (arising from monetary policy actions), which cloud the interpretation and are not material to the analysis. Also, for this reason, nominal imports are defined as real imports multiplied by the relative import price. To be consistent with our relative price measures, the real exchange rates that we report use output prices rather than consumer prices. The behavior of the real exchange rate defined using consumer prices is broadly consistent with our measure.
} 
sharp rise in relative import prices, while real imports decline much less in the two scenarios in which pass-through is low, in line with the comparatively muted responses of import prices.

The lower-left panel shows the behavior of nominal imports. For Scenario 1, nominal imports initially rise sharply - consistent with the run-up in import prices and indicative of a J-curve effect-but then fall off as the real quantity of imports declines over time. For the other two cases, moves in nominal imports are modest, as the rise in prices nearly offsets the decline in quantities. One point should be emphasized. As noted above, these simulations have been run with the price elasticity of import demand set equal to one. Holding activity constant, this unitary trade-price elasticity means that a rise in the relative price of imports triggers a proportionate drop in import quantities, leaving nominal expenditure on imports unchanged. Thus, the fact that nominal imports are down relative to baseline in Scenario 1 and 3 reflects general-equilibrium feedback effects as tighter monetary policy slows domestic demand (consumption), which - in turn-weighs on imports. ${ }^{13}$ A related observation is that if the price elasticity of import demand is greater than unity, the decline in both real and nominal imports is correspondingly greater as import price pass-through rises.

We now examine the behavior of the home country's exports. High import price passthrough in the foreign market means that exporters maintain their domestic-currency prices in the face of exchange rate changes. Accordingly, as shown in the upper-left panel of Figure 3, there is very little movement in the price of exports relative to the price of domestic output in the two cases in which import price pass-through in the foreign market is high (Scenarios 1 and 3). In contrast, when import price pass-through in the foreign market is low (Scenario 2), the home currency price of exports moves up markedly. ${ }^{14}$ As seen in the upper-right panel, in the cases with high foreign import price pass-through, the export price - expressed in terms of foreign currency (or, equivalently, the foreign import price) - falls significantly; and, as seen in

\footnotetext{
${ }^{13}$ In general equilibrium, nominal imports also respond to shifts in the price of imports relative to the price of all goods purchased in the home economy. Such relative price effects explain why nominal imports remain unchanged in Scenario 2 despite a fall in aggregate consumption.

${ }^{14}$ Note that in this model export prices do not feed directly into domestic inflation. However, a shift in export prices may affect inflation indirectly by stimulating the production of exports and, thus, raising actual GDP relative to potential.
} 
the lower left-panel, the quantity of home exports posts a corresponding rise. In the case in which pass-through is low, the price in terms of foreign currency falls only modestly, and the volume of home exports consequently rises only a little.

The bottom-right panel considers the home country's nominal exports. In all three scenarios, we see a marked rise in nominal exports, but the impetus for the rise differs significantly with pass-through. In the low pass-through case, Scenario 2, quantities move relatively little, but domestic-currency prices step up with the exchange rate. In the other two cases, the export price in domestic-currency terms is little changed, but quantities rise briskly. Given that the response of export prices to the exchange rate is more rapid than for export quantities, the move up in nominal exports occurs more quickly in Scenario 2 than in the other two scenarios.

As above, we underscore that the response of nominal exports depends crucially on the price elasticity of export demand. Our simulations set this elasticity equal to unity. In partial equilibrium, this unitary elasticity means that foreign expenditure on home exports is constant in foreign-currency terms (as prices and quantities move proportionately but in opposite directions). However, given that the domestic currency has depreciated, export earnings expressed in terms of the home currency rise proportionately with the fall in the exchange rate; thus, a one percent depreciation of the exchange rate raises home export revenues by one percent. ${ }^{15}$ In partial equilibrium, this "translation effect" for export earnings is what drives adjustment of the nominal trade balance regardless of the degree of pass-through. In general equilibrium, however, there are additional effects. Most important, an easing of monetary policy abroad, in response to the appreciation of the currency, stimulates foreign demand and consequently raises the home country's exports. This effect is particularly large in Scenarios 1 and 3-cases where foreign import price pass-through is high and, as a result, where the foreign monetary policy response is relatively aggressive. Finally, as before, we note that if the price elasticity of export demand exceeds one, the response of exports in the high pass-through cases rises, while the opposite result occurs if the trade-price elasticity is less than one.

\footnotetext{
${ }^{15}$ This point is shown analytically in Appendix A.
} 
We now look at several measures of the home country's external balance to assess the bottom-line impact on external adjustment. First, to assess the implications for real trade volumes, we consider the evolution of the ratio of real exports to real imports, which we call the "real trade balance." 16 As shown in the upper-left panel of Figure 4, when import price pass-through is low, the adjustment in the real trade balance is relatively muted. In contrast, real adjustment is most significant in the scenario in which import price pass-through is high in both countries - in this case real exports rise and real imports fall. The case in which import price pass-through is low at home but high abroad is between the two others, reflecting a large response from real exports but little response from real imports.

We now consider the ratio of nominal exports to nominal imports - our measure of the nominal trade balance. As displayed in the upper-right panel, the results here are much more similar across the three scenarios (at least after five quarters or so) than is the case for the real trade balance, as shifts in the terms of trade (i.e., export prices relative to import prices) tend to offset the effects of real adjustment. Specifically, as shown in the lower-left panel, when import price pass-through is high, the domestic country's terms of trade decline significantly as import prices rise relative to export prices. (Indeed, it is the rise in import prices that triggers the decline in real imports). In the case in which pass-through is low, export prices rise significantly relative to import prices, and the terms of trade improve substantially. This improvement in the terms of trade fuels nominal adjustment in this scenario. In our asymmetric case, both import prices and export prices are comparatively little changed, so the terms of trade move less than in the other scenarios.

Thus, the nominal trade balance improves in all three scenarios. In the high pass-through world, adjustment occurs as declines in real imports and increases in real exports are offset by a deterioration in the terms of trade. ${ }^{17}$ When import price pass-through at home and abroad

\footnotetext{
${ }^{16} \mathrm{We}$ show the real and nominal trade balances as ratios of exports to imports (rather than as exports minus imports) in order to match the framework developed in Appendix A and for analytical tractability. None of our qualitative results depend on this definition, and the simulation results for the trade balance as a share of GDP use the more conventional measure of the trade balance - nominal exports minus nominal imports.

${ }^{17}$ This case shows a short-lived J-curve effect, as the sharp, immediate rise in import prices temporarily dominates the adjustment in quantities.
} 
is low, quantities move little, but the terms of trade improve significantly (due to a sharp and immediate rise in export prices denominated in domestic currency). In the asymmetric case, adjustment is driven entirely by a surge in export quantities. The results for the trade balance as a share of GDP (the lower-right panel) are broadly similar to those for the ratio of nominal exports to nominal imports. ${ }^{18}$

As outlined in Appendix A, in partial equilibrium, the response of the nominal trade balance to changes in exchange rates will be the same regardless of the degree of exchange rate pass-through. ${ }^{19}$ Key assumptions in deriving this result are that a move in the exchange rate operates on home and foreign import demand exclusively through its effect on relative prices and that there is no change in import demand arising from shifts in the level of domestic activity. Thus, the fact that the three scenarios manifest varying degrees of improvement in the nominal trade balance reflects the differing general-equilibrium effects of exchange rate changes under varying pass-through assumptions. These general-equilibrium effects are most significant in the high pass-through world, as the marked tightening of domestic monetary policy compresses domestic demand and, consequently, the home country's nominal imports, and the symmetric easing of foreign monetary policy supports foreign demand, boosting the home country's exports as well. In the low pass-through world, the required monetary policy response at home and abroad is smaller, and, as a result, the improvement in the nominal trade balance is more muted. In the asymmetric case, which lies between the other two, nominal exports are supported by a relatively aggressive tightening of foreign monetary policy.

More broadly, the magnitude and direction of such general equilibrium feedback effects depends on a variety of features of the home and foreign economies. ${ }^{20}$ That said, our work

\footnotetext{
${ }^{18}$ Notably, the conclusion that the relative contributions of real quantities and the terms of trade to nominal adjustment varies systematically with pass-through is largely independent of the trade-price elasticities. As the trade-price elasticities rise above one (fall below one), the strength of the quantity response is accordingly amplified (damped), but the qualitative story outlined in the simulations is otherwise unchanged.

${ }^{19}$ Appendix A also shows that the traditional Marshall-Lerner condition must be modified if pass-through to trade prices is incomplete.

${ }^{20}$ These features include the sensitivity of import prices to the exchange rate (pass-through), of import quantities to shifts in import prices (the trade-price elasticity), of domestic prices to moves in import prices, of the monetary policy response to an incipient rise in domestic inflation, of domestic demand to moves in real policy rates, and of imports to a shift in domestic demand.
} 
suggests that under the maintained assumption of unitary trade-price elasticities - but allowing many of the other features of these economies to vary in plausible ways - general equilibrium feedback effects typically support improvement (sometimes marked improvement) in the home country's nominal trade balance following a weakening of its currency. Such effects, however, become more muted as pass-through declines.

As noted above, a feature of our simulations is that the demand for imports depends on real domestic demand. If imports depended instead on real output, their response to a move in the exchange rate (including feedback effects through monetary policy) would be more subdued. This is the case because the currency depreciation stimulates real net exports and, as a result, real output tends to fall by less than is the case for domestic demand-indeed, as our simulations suggest, real output may even rise.

Results for the Foreign Economy. The final figure illustrates that in our baseline scenarios the results for the foreign country are essentially a mirror image of those for the home country. Specifically, the initial risk premium shock implies that the foreign currency appreciates against the home currency. The middle-left panel displays the implications for the foreign country's real trade balance. The general ordering is that as import price pass-through in either the home country or the foreign country rises, the deterioration in the foreign country's real trade balance becomes more pronounced. On the other hand, an increase in import price pass-through in either the home country or the foreign country also means that the behavior of the terms of trade following an exchange rate appreciation is more favorable (the bottom-left panel). As noted above, these two effects have offsetting implications. For this reason, the responses of the foreign country's nominal trade balance (the middle-right panel) and its trade balance as a share of GDP (the bottom-right panel) are - after a few quarters - much more similar across the three scenarios than is the case for the real trade balance. 


\section{Conclusions and Key Findings}

Several broad conclusions emerge from our work. First, a decline in the exchange rate sensitivity of trade prices reduces the responsiveness of real imports and real exports to moves in the exchange rate and, thus, inhibits adjustment of the real trade balance. We find this result to be very robust. However, as indicated above, while real adjustment contributes to long-run external sustainability, it is neither necessary nor sufficient. Improvement in the nominal trade balance - the central, indispensable feature of external adjustment - can also be achieved by a shift in the terms of trade.

Second, when the analysis is restricted to a partial-equilibrium setting - and assuming that the price elasticities of import and export demand are near one - the degree of exchange rate pass-through to import and export prices has little effect on the adjustment of the nominal trade balance. Regardless of the degree of pass-through, a depreciation of the exchange rate triggers a proportionate rise in export earnings, as unchanged foreign expenditure on home exports (denominated in foreign currency) is equivalent to a correspondingly higher amount of home currency. This "translation effect" for export earnings is what drives adjustment of the nominal trade balance in partial equilibrium. That said, we also find that the relative importance of shifts in real quantities versus moves in the terms of trade varies significantly with the extent of exchange rate pass-through.

Third, if trade-price elasticities are greater than one, a decline in pass-through in either the home or the foreign country will result in less adjustment of the nominal trade balance following an exchange rate move. Conversely, if the trade-price elasticities are less than one, a decline in import price pass-through will facilitate adjustment.

Finally, in general equilibrium, when we consider the effects of the monetary policy response to the exchange rate shock, we find that a decline in import price pass-through either at home or abroad attenuates nominal adjustment. Specifically, lower pass-through makes domestic inflation and output less sensitive to the depreciation of the exchange rate and, as a result, the required tightening of monetary policy is less pronounced. The reduced policy response means that domestic demand is compressed to a lesser extent, which suggests a smaller 
decline in nominal imports and thus less improvement in the nominal trade balance. (Symmetric effects occur abroad, with corresponding implications for home exports.) However, even if the general-equilibrium effects are muted entirely, the channels of adjustment identified in the partial-equilibrium analysis are still operative. 


\section{References}

Adolfson, M., 2004, "Exchange Rate Pass-through-Theory, Concepts, Beliefs and Some Evidence," mimeo, Sveriges Riksbank.

Anderson, G., 1997, "A Reliable and Computationally Efficient Algorithm for Imposing the Saddle Point Property in Dynamic Models", Occasional Staff Studies 4, Board of Governors of the Federal Reserve System.

Anderson G. and G. Moore, 1985, "A Linear Algebraic Procedure for Solving Linear Perfect Foresight Models," Economic Letters 17, 247-52.

Atkeson, A. and A. Burnstein, 2005, "Trade Costs, Pricing to Market, and International Relative Prices," mimeo, University of California at Los Angeles.

Bank for International Settlements, 2005, 75th Annual Report, Basel, Switzerland.

Betts, C. and M. Devereux, 1999, "The International Effects of Monetary and Fiscal Policy in a Two-Country Model", Discussion paper no. 99-10, University of British Columbia.

Blanchard, O. and C. Kahn, 1980, "The Solution of Linear Difference Models under Rational Expectations", Econometrica 48, 1305-1311.

Bergin, P. and R. Feenstra, 2001, "Pricing-to-Market, Staggered Contracts, and Real Exchange Rate Persistence," Journal of International Economics 54, 333-59.

Bodnar, G., B. Dumas, and R. Marston, 2002, "Pass Through and Exposure," Journal of Finance 57(1), 199-231.

Campa, J., and L. Goldberg, 2004, "Exchange Rate Pass Through Into Import Prices," CEPR Discussion Papers 4391.

Corsetti, G. and L. Dedola, 2002, "Macroeconomics of International Price Discrimination," Journal of International Economics, forthcoming. 
Corsetti, G., L. Dedola, and S. Leduc, 2005, "DSGE Models of High Exchange-Rate Volatility and Low Pass-Through," Board of Governors of the Federal Reserve System International Finance Discussion Papers 845.

Dotsey, M. and R. King, 2005, "Implications of State-Dependent Pricing for Dynamic Macroeconomic Models," Journal of Monetary Economics 52, 213-42.

Ellis, L., 2004, "Exchange Rates and Monetary Policy: the Australian Context," mimeo, Reserve Bank of Australia.

Erceg, C., L. Guerrieri, and C. Gust, 2005, "SIGMA: A New Open Economy Model for Policy Analysis," Board of Governors of the Federal Reserve System International Finance Discussion Papers 835 .

Frankel, J., D. Parsley, and S. Wei, 2005, "Slow Pass-through around the World: A New Import for Developing Countries?" NBER Working Paper 11199.

Gust, C., S. Leduc, and R. Vigfusson, 2005, "Trade Integration, Competition, and the Decline in Exchange Rate Pass-through," mimeo, Federal Reserve Board.

Heath, A., I. Roberts, and T. Bulman, 2004, "Inflation in Australia: Measurement and Modelling," in C. Kent and S. Guttmann (eds), The Future of Inflation Targeting, Reserve Bank of Australia, Sydney, 167-207.

Hooper, P. and J. Marquez, 1995, "Exchange Rates, Prices, and External Adjustment in the United States and Japan." In Kenen, P. (ed) Understanding Independence, Princeton University Press, Princeton N.J., 1995, 107-68.

Hooper, P., K. Johnson, and J. Marquez, 2000, "Trade Elasticities for the G-7 Countries" Princeton Studies in International Economics, 87.

Ihrig, J., M. Marazzi, and A. Rothenberg, 2005, "Exchange-Rate Pass-Through in the G-7 Economies," mimeo, Federal Reserve Board. 
International Monetary Fund, 2005, "United States: Selected Issues," Washington, DC.

Kimball, M., 1995, "The Quantitative Analytics of the Noemonetarist Model," Journal of Money, Credit, and Banking 27, 1241-77.

Laxton, D. and P. Pesenti, 2003, "Monetary Rules for Small, Open, Emerging Economies," Journal of Monetary Economics, 50, 1109-1146.

Marazzi, M., N. Sheets, and R. Vigfusson, with J. Faust, J. Gagnon, J. Marquez, R. Martin, T. Reeve, and J. Rogers, 2005, "Exchange Rate Pass-Through to U.S. Import Prices: Some New Evidence," Board of Governors of the Federal Reserve System International Finance Discussion Papers 833.

Marquez, J., 2002, Estimating Trade Elasticities, Dordrecht, The Netherlands, Kluwer Academic Publishers.

Nessen, M., 2004, "Exchange Rate Pass-through, Inflation, and Monetary Policy," mimeo, Sveriges Riksbank.

Otani, A., S. Shiratsuka, and T. Shirota, 2003, "The Decline in the Exchange Rate PassThrough: Evidence from Japanese Import Prices," Monetary and Economic Studies 21, 53-81.

Peltzman, S., 2000, "Prices Rise Faster Than They Fall," Journal of Political Economy 108, 466-502.

Sekine, T., 2005, "Time-Varying Exchange Rate Pass-through: Experience of Some Industrial Countries," mimeo, Bank of International Settlements.

Senhadji, A. and C. Montenegro, 1999, "Time Series Analysis of Export Demand Equations: A Cross-Country Analysis," IMF Staff Papers, 46, 259-73.

Smets, F. and R. Wouters, 2003, "An Estimated Dynamic Stochastic General Equilibrium Model of the Euro Area," Journal of the European Economic Association, Vol. 1, 1124-1175.

Woodford, M., 2003, Interest and Prices, Princeton and Oxford: Princeton University Press. 


\section{Appendix}

This appendix is divided into two parts. In Appendix A, we examine analytically the partial-equilibrium relationship between exchange rate pass-through to import and export prices and adjustment of the trade balance. In Appendix B, we provide a detailed description of the general-equilibrium features of SIGMA-PT, the model used in our simulations.

\section{A Partial-Equilibrium Framework}

In this appendix, we provide a partial-equilibrium framework for analyzing the relationship between exchange rate pass-through to import and export prices and the trade balance. This analysis can be viewed as a special case of SIGMA-PT in that it abstracts from some of dynamic aspects of that model. ${ }^{21}$ By doing so, it provides a simple framework for demonstrating that the exchange rate sensitivity of import and export prices is an important determinant of trade flows. We also derive the result that when trade-price elasticities are unity, a one percent depreciation of the exchange rate improves the trade balance by roughly one percent of the value of exports, regardless of the extent of pass-through.

Our framework consists of a home and foreign economy. In what follows, we focus on describing the home economy, since the foreign economy is symmetric to the home economy. The home economy is populated by a large number of households and firms. Firms are imperfectly competitive and produce a differentiated product that is sold to households located in the firm's home country and households located abroad. A household's overall consumption is therefore made up of a large number of domestically-produced and imported goods.

Household demand for one of these imported goods, $M_{t}$, is a function of its price relative to the average price of competing goods and a household's total consumption:

$$
M_{t}=D\left(\frac{e_{t} P_{m t}^{*}}{\Gamma_{t}}, C_{t}\right)
$$

\footnotetext{
${ }^{21}$ In particular, the partial equilibrium analysis abstracts from nominal price and wage rigidities and adjustment costs on imports. We also assume that the labor market is competitive, which can be approximated in SIGMA-PT by setting $\gamma_{w}$ close to one.
} 
In this expression, $P_{m t}^{*}$ denotes the price of the imported good in foreign currency units and $e_{t}$ denotes the exchange rate expressed in units of the home currency relative to the foreign currency. The competitive price index, $\Gamma_{t}$, is made up of the prices of all domestic and foreign producers who sell their goods to the household. Similarly, demand for a domestically-produced good by a household in the home country can be written as $D\left(\frac{P_{d t}}{\Gamma_{t}}, C_{t}\right)$ where $P_{d t}$ denotes the price of a domestically-produced good.

We assume that the home and foreign market are segmented so that a firm can sell its goods at different prices in the two markets. We also assume that firms in the home economy all have the same marginal cost, which is equal to the economy's nominal wage, $W_{t}{ }^{22}$ In this case, profits for a firm located in the domestic economy are given by:

$$
\pi_{i t}=\left(P_{d t}-W_{t}\right) D\left(\frac{P_{d t}}{\Gamma_{t}}, C_{t}\right)+\left(P_{x t}-W_{t}\right) D\left(\frac{P_{x t}}{e_{t} \Gamma_{t}^{*}}, C_{t}^{*}\right)
$$

where $P_{x t}$ is the home currency price set by the producer in the foreign market, $\Gamma_{t}^{*}$ is the average price of the firm's competitors in the foreign market, and $C_{t}^{*}$ is overall consumption demanded by a household in the foreign market.

A firm chooses its prices to maximize its profits taking wages, the exchange rate, the prices of its competitors, and the demand curve as given. Taking a first-order logarithmic approximation of a firm's optimal pricing equation for $P_{x t}$ yields the following relationship:

$$
\hat{P}_{x t}=\beta_{x} \hat{W}_{t}+\left(1-\beta_{x}\right)\left(\hat{\Gamma}_{t}^{*}+\hat{e}_{t}\right)
$$

where the symbol "^, denotes the logarithmic deviation of a variable from its steady-state value, and $\beta_{x}$ is a coefficient determining the responsiveness of a firm's export price to its marginal cost satisfying $0 \leq \beta_{x} \leq 1$. With $\beta_{x}<1$, a home exporter finds it optimal to adjust its price in response to the prices of its competitors and will not fully pass through changes in marginal costs because of the competitive disadvantage that it implies. Since a foreign exporter behaves in an identical manner, there is a similar relationship for the price of a good imported to the

\footnotetext{
${ }^{22}$ Implicitly, we have assumed that a firm's production is linear and depends only on labor. The labor market is also competitive, and labor is completely mobile within a country but immobile across countries.
} 
home country:

$$
\hat{P}_{m t}=\beta_{m}\left(\hat{W}_{t}^{*}+\hat{e}_{t}\right)+\left(1-\beta_{m}\right) \hat{\Gamma}_{t}
$$

where $0 \leq \beta_{m} \leq 1, \hat{P}_{m t}=\hat{P}_{m t}^{*}+\hat{e}_{t}$, and $W_{t}^{*}$ is the nominal wage in the foreign economy.

While a change in the exchange rate can affect a firm's pricing behavior indirectly by affecting wages or the prices of a firm's competitors, it is instructive to focus on only the direct effects. We compute the direct effect by holding $W_{t}$ and $\Gamma_{t}$ constant and partially differentiating the prices in equations (A.3) and (A.4) with respect to the exchange rate:

$$
\frac{\partial \hat{P}_{x t}}{\partial \hat{e}_{t}}=1-\beta_{x} \quad \text { and } \quad \frac{\partial \hat{P}_{m t}}{\partial \hat{e}_{t}}=\beta_{m} .
$$

According to (A.5), a one percent depreciation of the home currency (i.e., an increase in $e_{t}$ ) leads to an increase in the import price paid by a home household of $\beta_{m}$ and an increase in a home firm's export price of $1-\beta_{x}$. (The corresponding import price paid by a foreign household falls by $\beta_{x}$ ). Thus, we equate $\beta_{m}$ with pass-through to the import price and $1-\beta_{x}$ with pass-through of the exchange rate to the export price.

With pass-through defined in this way, we now turn to examining the implications of various values of $\beta_{x}$ and $\beta_{m}$ for trade adjustment. Since trade adjustment depends on trade volumes, it is convenient to log-linearize the import demand equation (A.1) around steady state:

$$
\hat{M}_{t}=-\alpha_{m}\left(\hat{P}_{m t}-\hat{\Gamma}_{t}\right)+\hat{C}_{t}
$$

where $\alpha_{m}>0$ is the elasticity of the import good $M_{t}$ with respect to its relative price, $\frac{P_{m t}}{\Gamma_{t}}$. Household demand for good $M_{t}$ therefore increases with a rise in overall demand $C_{t}$ and decreases with a rise in the relative price of the good. Foreign household demand implies a similar condition for a home exporter's good:

$$
\hat{X}_{t}=-\alpha_{x}\left(\hat{P}_{x t}-\hat{e}_{t}-\hat{\Gamma}_{t}^{*}\right)+\hat{C}_{t}^{*}
$$

where $\alpha_{x}>0$ is the elasticity of a home exporter's good $X_{t}$ with respect to its relative price.

The response of real exports and imports to an exchange rate change depends crucially on the values of $\beta_{x}$ and $\beta_{m}$. This importance can be seen by partially differentiating $M_{t}$ and 
$X_{t}$ with respect to the exchange rate, holding other firms' prices and overall demand in both countries constant:

$$
\frac{\partial \hat{M}_{t}}{\partial \hat{e}_{t}}=-\alpha_{m} \frac{\partial \hat{P}_{m t}}{\partial \hat{e}_{t}}=-\alpha_{m} \beta_{m} \quad \text { and } \quad \frac{\partial \hat{X}_{t}}{\partial \hat{e}_{t}}=-\alpha_{x}\left(\frac{\partial \hat{P}_{x t}}{\partial \hat{e}_{t}}-1\right)=\alpha_{x} \beta_{x}
$$

According to (A.8), a one percent depreciation of the home currency induces a larger decrease in real imports when import price pass-through is high. Similarly, the depreciation leads to a larger increase in exports when the export price is insensitive to the exchange rate (i.e., $\beta_{x}=1$ so that import price pass-through in the foreign country is complete). Thus, adjustment of real trade volumes in response to an exchange rate change will be larger when pass-through to import prices in both countries is complete.

To examine the relationship between pass-through and the nominal trade balance, it is convenient to define the ratio of nominal exports to imports, $\tau_{t}=\frac{P_{x t} X_{t}}{P_{m t} M_{t}}$. Expressing this ratio as a log-deviation from steady state:

$$
\hat{\tau}_{t}=\hat{P}_{x t}-\hat{P}_{m t}+\hat{X}_{t}-\hat{M}_{t}
$$

it is clear that nominal adjustment depends on the responses of the terms of trade, $\frac{P_{x t}}{P_{m t}}$, and real net exports, $\frac{X_{t}}{M_{t}}$. Using expressions (A.5) and (A.8), the partial effect of an exchange rate change on $\tau_{t}$ is given by:

$$
\frac{\partial \hat{\tau}_{t}}{\partial \hat{e}_{t}}=\left(\frac{\partial \hat{P}_{x t}}{\partial \hat{e}_{t}}-\frac{\partial \hat{P}_{m t}}{\partial \hat{e}_{t}}\right)+\frac{\partial \hat{X}_{t}}{\partial \hat{e}_{t}}-\frac{\partial \hat{M}_{t}}{\partial \hat{e}_{t}}=\left(1-\beta_{x}-\beta_{m}\right)+\alpha_{x} \beta_{x}+\alpha_{m} \beta_{m} .
$$

The first term in the parentheses is the effect of an exchange rate change on the terms of trade, and the other two terms are the effects of the exchange rate change on real trade volumes. If the trade-price elasticities are equal to unity (i.e., $\alpha_{x}=\alpha_{m}=1$ ), then nominal adjustment is independent of the pass-through assumptions, and the nominal trade balance will increase by one percent of the value of exports in response to a one percent depreciation of the home currency. In this case, nominal adjustment is independent of pass-through, because in both the home and foreign country nominal expenditures on imports are unchanged, as movements 
in domestic currency prices are offset by proportionate shifts in real imports. The home trade balance improves in response to a depreciation of the home currency, however, because the unchanged foreign expenditures on imports translates into increased home-currency export receipts. However, it is important to note that this result is only applicable in partial equilibrium, as we have abstracted from changes in $C_{t}$ and $C_{t}^{*}$ that may arise in general equilibrium. ${ }^{23}$

Although in partial equilibrium the response of the trade balance is independent of the pass-through assumptions when $\alpha_{x}=\alpha_{m}=1$, the forces that bring about trade balance adjustment are different in a low and high pass-through environment. In a high pass-through environment (i.e., $1<\beta_{x}+\beta_{m}$ ), the nominal trade balance rises in response to a depreciation, as real net exports increase enough to offset a fall in the terms of trade. By contrast, in a low pass-through environment (i.e., $0 \leq \beta_{x}+\beta_{m}<1$ ), the terms of trade increase in response to a depreciation and both the rise in the terms of trade and higher real net exports contribute to an increase in the trade balance.

If $\alpha_{x}, \alpha_{m}>1$, then higher values of $\beta_{x}$ and $\beta_{m}$ induce greater trade balance adjustment. With $\alpha_{m}>1$, both real and nominal imports fall in response to a depreciation. Because this decline is greater for higher values of $\beta_{m}$, a higher value of $\beta_{m}$ is associated with more trade balance adjustment. Similarly, with $\alpha_{x}>1$, real and nominal exports rise following a depreciation and this increase is larger for higher values of $\beta_{x}$.

If $\alpha_{x}, \alpha_{m}<1$, then higher values of $\beta_{x}$ and $\beta_{m}$ inhibit nominal adjustment. In this case, nominal imports rise in response to a depreciation, because the depreciation has a larger effect on the price of imports than on real imports. Nominal trade adjustment is inhibited for larger values of $\beta_{m}$, because the higher value of $\beta_{m}$ leads to a greater increase in import prices and nominal imports following the depreciation. Moreover, with $\alpha_{x}<1$, nominal exports denominated in domestic currency still increase in response to a depreciation but the increase is smaller for higher values of $\beta_{x}$.

It is also interesting to note that the usual Marshall-Lerner condition needs to be modified in an environment with incomplete pass-through. This condition states that for a depreciation

\footnotetext{
${ }^{23}$ As suggested by the simulations of the general equilibrium model, these changes in demand can vary considerably under different assumptions about pass-through.
} 
of the domestic currency to lead to a rise in the trade balance, the sum of the export and import price elasticities must be greater than one (i.e., $\alpha_{x}+\alpha_{m}>1$ ). However, this condition is derived assuming complete pass-through. From equation (A.10), we can see that for a depreciation to induce an improvement in the trade balance, it must be true that:

$$
\alpha_{x} \beta_{x}+\alpha_{m} \beta_{m}>\beta_{x}+\beta_{m}-1
$$

In the complete pass-through environment $\left(\beta_{x}=\beta_{m}=1\right)$, this condition is the same as the usual Marshall-Lerner condition. More generally, this modified version of the Marshall-Lerner condition states that for a depreciation of the domestic currency to lead to an increase in the trade balance then its stimulative effects on real exports and real imports must be greater than its effect on the terms of trade. Notably, if import price pass-through both at home and abroad is equal to zero (i.e., $\beta_{x}=\beta_{m}=0$ ), then equation (A.11) is satisfied regardless of the values of the trade-price elasticities.

\section{B Description of SIGMA-PT}

Our model consists of a home and a foreign economy. These two economies have isomorphic structures so in our exposition we focus on describing only the domestic economy. The domestic economy consists of two types of agents: households and firms. Households supply their labor to firms and are monopolistic competitors in labor markets to account for aggregate wage stickiness. Household utility depends on the consumption of both domestically-produced goods and imported goods. These goods are purchased from monopolistically competitive firms, who sell their goods to both domestic and foreign households. This monopolistically competitive setup allows us to rationalize stickiness in both domestic and international prices.

We consider two alternative specifications of our model. The first specification allows for incomplete pass-through by specifying a demand curve with a non-constant elasticity so that a firm's price decision depends on the pricing decisions of its competitors. An additional reason pass-through is incomplete in this specification is that a firm's export price is sticky in 
local currency terms. In our alternative specification, pass-through is complete, as a firm sets a constant desired markup over marginal cost and faces no rigidities in adjusting its export price.

\section{B.1 Households}

We assume a continuum of monopolistically competitive households (indexed on the unit interval), each of which supplies a differentiated labor service. It is convenient to assume that a household sells its labor services to a representative labor aggregator (or "employment agency"). The aggregator combines each household's labor services into an aggregate labor index $L_{t}$ according to:

$$
L_{t}=\left[\int_{0}^{1}\left(N_{t}(h)\right)^{\gamma_{w}} d h\right]^{\frac{1}{\gamma_{w}}}
$$

where $1>\gamma_{w}>0$ and $N_{t}(h)$ is hours worked by a typical member of household $h$. The aggregator minimizes the cost of producing a given amount of the aggregate labor index, taking each household's wage rate $W_{t}(h)$ as given, and then sells units of the labor index to the economy's firms at their unit cost $W_{t}$ :

$$
W_{t}=\left[\int_{0}^{1} W_{t}(h)^{\frac{\gamma_{w}}{\gamma_{w}-1}} d h\right]^{\frac{\gamma_{w}-1}{\gamma_{w}}}
$$

It is natural to interpret $W_{t}$ as the aggregate wage index. The aggregator's demand for the labor services of household $h$ is given by

$$
N_{t}(h)=\left[\frac{W_{t}(h)}{W_{t}}\right]^{\frac{1}{\gamma_{w}-1}} L_{t}
$$

The utility functional of household $h$ is

$$
E_{t} \sum_{j=0}^{\infty} \beta^{j}\left\{\log \left(C_{t+j}(h)-\varkappa C_{t+j-1}\right)-\frac{\chi_{0}}{1+\chi} N_{t+j}(h)^{1+\chi}\right\},
$$

where the discount factor $\beta$ satisfies $0<\beta<1$. As in Smets and Wouters (2003), we allow for the possibility of external habits, where household $h$ cares about its consumption relative to lagged aggregate consumption. The period utility function also depends on labor hours, $N_{t}(h)$. 
Household $h$ faces a flow budget constraint in period $t$ which states that its expenditure on consumption goods and on the net accumulation of financial assets must equal its disposable income:

$$
\begin{gathered}
P_{C t} C_{t}(h)+\int_{s} \xi_{t, t+1} B_{D t+1}(h)-B_{D t}(h)+\frac{e_{t} P_{B t}^{*} B_{F t+1}(h)}{\phi_{b t}}-e_{t} B_{F t}(h)= \\
W_{t}(h) N_{t}(h)\left[1-\phi_{w t}(h)\right]+\Gamma_{t}(h) .
\end{gathered}
$$

In equation (B.5), $P_{C t}$ denotes the price of the consumption good. We assume that a household can engage in frictionless trading of a complete set of contingent claims with other domestic households. We denote $\xi_{t, t+1}$ as the price of an asset that pays one unit of domestic currency in a particular state of nature at date $t+1$ (for notational simplicity, we have suppressed all of the state indices), while $B_{D t+1}(h)$ represents the quantity of such claims purchased by a household at time $t$. Thus, the gross outlay on new state-contingent domestic claims is given by integrating over all states at time $t+1$, and $B_{D t}(h)$ indicates the value of the household's existing claims given the realized state of nature at time $t$.

While asset markets are complete within a country, we assume that trade in international assets is restricted to a non-state contingent nominal bond. Accordingly, in equation (B.5), $B_{F t+1}(h)$ represents the quantity of a non-state contingent asset purchased at time $t$ that pays one unit of foreign currency in the subsequent period. $P_{B t}^{*}$ is the foreign currency price of the bond, and $e_{t}$ is the exchange rate expressed in units of home currency per unit of foreign currency. We follow Turnovsky (1985) and assume there is an intermediation cost $\phi_{b t}$ paid by households in the home country for purchases of foreign bonds, which ensures that net foreign assets are stationary in the model. ${ }^{24}$ More specifically, the intermediation costs depend on the ratio of economy-wide holdings of net foreign assets to nominal output and are given by:

$$
\phi_{b t}=\exp \left[-\phi_{b}\left(\frac{e_{t} B_{F t+1}}{P_{D t} Y_{t}}\right)+\nu_{b t}\right] .
$$

\footnotetext{
${ }^{24}$ This intermediation cost is asymmetric, as foreign households do not face these costs. Rather, they collect profits on the monopoly rents associated with these intermediation costs.
} 
In the above, $\nu_{b t}$ is a mean-zero stochastic process, which we interpret as a risk-premium shock or a shock to the uncovered interest-rate parity condition. Abstracting from this shock, if the home economy in aggregate is a net lender, then a household will earn a lower return on any holdings of foreign bonds. By contrast, if the economy is a net debtor, a household will pay a higher return on any foreign debt.

A household's disposable income consists of its labor income and an aliquot share, $\Gamma_{t}(h)$, of the profits of the domestic firms. The term $\phi_{w t}(h)$ reflects that a household incurs a cost to adjusting its wages, and these costs are given by:

$$
\phi_{w t}(h)=\frac{\phi_{w}}{2}\left(\frac{\frac{W_{t}(h)}{W_{t-1}(h)}}{\frac{W_{t-1}}{W_{t-2}}}-1\right)^{2} .
$$

As in Laxton and Pesenti (2003), our specification of wage adjustment depends on a household's wage inflation relative to last period's aggregate wage inflation. ${ }^{25}$

In every period $t$, a household maximizes the utility functional (B.4) with respect to consumption, holdings of contingent claims, holdings of the international asset, and its wage subject to its labor demand function (B.3) and budget constraint (B.5). In doing so, a household takes as given prices and aggregate quantities such as lagged aggregate consumption and the aggregate net foreign asset position.

\section{B.2 Demand Aggregator}

Consumption of household $h$ is made up of a continuum of domestically-produced goods, $C_{d t}(i, h)$, indexed by $i \in[0,1]$, and a continuum of imported goods, $C_{m t}(j, h), j \in[0, \omega]$. Household $h$ chooses $C_{d t}(i, h)$ and $C_{m t}(j, h)$ to minimize its total expenditures:

$$
\left[\int_{0}^{1} P_{d t}(i) C_{d t}(i, h) d i+\int_{0}^{\omega} P_{m t}(j) C_{m t}(j, h) d j\right],
$$

subject to $D\left(\frac{C_{d t}(i, h)}{C_{t}(h)}, \frac{C_{m t}(j, h)}{C_{t}(h)}\right)=1$. In the above, the parameter, $\omega$, may be interpreted as determining the degree of home bias in a household's consumption expenditures, as we assume

\footnotetext{
${ }^{25}$ We also considered quadratic adjustment costs penalizing changes in a household's wage relative to its wage last period. This made little difference in our results.
} 
that domestic household's purchase a greater variety of home goods than foreign goods since $\omega<1$. The function, $D\left(\frac{C_{d t}(i, h)}{C_{t}(h)}, \frac{C_{m t}(j, h)}{C_{t}(h)}\right)$, is a household's demand aggregator defined as:

$$
D\left(\frac{C_{d t}(i, h)}{C_{t}(h)}, \frac{C_{m t}(j, h)}{C_{t}(h)}\right)=\left[V_{d t}(h)^{1 / \rho}+V_{m t}(h)^{1 / \rho}\right]^{\rho}-\frac{1}{(1+\eta) \gamma}+1,
$$

where $V_{d t}(h)$ is an aggregator for domestic goods given by:

$$
V_{d t}(h)=\int_{0}^{1} \frac{1}{(1+\eta) \gamma}\left[(1+\eta) \frac{C_{d t}(i, h)}{C_{t}(h)}-\eta\right]^{\gamma} d i,
$$

and $V_{m t}(h)$ is an aggregator for imported goods given by:

$$
V_{m t}(h)=\int_{0}^{\omega} \frac{1}{(1+\eta) \gamma}\left[(1+\eta) \frac{\phi_{m t}(j, h) C_{m t}(j, h)}{C_{t}(h)}-\eta\right]^{\gamma} d j .
$$

The term $\phi_{m t}(j, h)$ reflects a cost incurred by households of adjusting their demand for $C_{m t}(j, h)$ relative to their overall consumption demand $C_{t}(h)$ :

$$
\phi_{m t}(j, h)=1-\frac{\phi_{m}}{2}\left(\frac{\frac{C_{m t}(j, h)}{C_{t}(h)}}{\frac{C_{m t-1}(j)}{C_{t-1}}}-1\right)^{2} .
$$

This specification implies that it is costly for household $h$ to change its share of imported good $j$ in its total consumption relative to the lagged economy-wide share of imported good $j$ in aggregate consumption. ${ }^{26}$ It has the attractive feature that the economy's import share is relatively unresponsive in the short-run to changes in the relative price of imported goods, even while allowing the level of imports to jump costlessly in response to changes in overall consumption demand. ${ }^{27}$ Thus, these adjustment costs influence the short-run price elasticity of import demand. In steady state, these adjustment costs are zero so that the price elasticity of import demand is independent of these adjustment costs.

Our demand aggregator adapts the one discussed in Dotsey and King (2005) to an international environment. ${ }^{28}$ It shares the central feature that the elasticity of demand is nonconstant

\footnotetext{
${ }^{26}$ We specify adjustment costs that depend on the lagged economy-wide import share for good $j$ rather than a household's import share to avoid time inconsistency issues associated with the optimization problem of the monopolistic producer of good $j$.

${ }^{27}$ Using aggregate data, Hooper, Johnson, and Marquez (2000) find that the short-run trade price elasticity is smaller than the long-run elasticity in a number of G-7 economies. This is qualitatively consistent with the results of industry studies, as surveyed by McDaniel (2003).

${ }^{28}$ Also, see Gust, Leduc, and Vigfusson (2005), who study the case in which $\rho=1$ and $\phi_{m}=0$.
} 
with $\eta \neq 0$, and the (absolute value of the) demand elasticity can be expressed as an increasing function of a firm's relative price, when $\eta<0 .{ }^{29}$ This feature has proven useful in the sticky price literature, because it helps mitigate a firm's incentive to raise its price after an expansionary monetary shock in the context of a model in which other firms have already preset their prices. It is also consistent with the evidence that firms tend to change their prices more in response to cost increases than decreases (see, for instance, Peltzman (2000)). Another important implication of this aggregator, more relevant for us, is that exchange-rate pass-through to import prices will be incomplete when the elasticity of demand is increasing in a firm's relative price. $^{30}$

Our aggregator differs from Dotsey and King (2005) by aggregating over foreign goods, and allowing for home bias in consumption expenditures. Accordingly, the aggregator of Dotsey and King (2005) can be viewed as a special case of equations (B.8) and (B.9) with $\rho=1$ and $\omega=0$. Another property of our aggregator is that with $\rho \neq 1$ the elasticity of substitution depends on whether the good was purchased at home or abroad. (In contrast, if $\rho=1$, then the elasticity of substitution is the same for all goods.) We view this feature as desirable, since it gives the model more flexibility to match both macro estimates of the price over cost markup and the import trade-price elasticity.

Expenditure minimization by household $h$ implies that its demand for import good $j$ is given by:

$$
C_{m t}(j, h)=\frac{1}{1+\eta}\left[\left(\frac{\tilde{P}_{m t}(j)}{\Gamma_{t}}\right)^{\frac{1}{\gamma-1}}\left(1+\frac{V_{d t}(h)}{V_{m t}(h)}\right)^{\frac{1-\rho}{\gamma-1}}+\eta\right] \frac{C_{t}(h)}{\phi_{m t}(j, h)} .
$$

In equation (B.13), $\tilde{P}_{m t}(j)$ is the effective import price for good $j$, since it reflects the cost of

\footnotetext{
${ }^{29}$ More precisely, with $\rho \neq 1$, the demand curve must satisfy $\frac{\eta \rho(1-\gamma)}{\rho-\gamma}<0$. With $\rho=1$, this condition simplifies to $\eta<0$.

${ }^{30}$ See, for example, Bergin and Feenstra (2001) who demonstrate that the interaction of their NCES demand curve with sticky prices-local currency pricing is useful in accounting for the observed volatility and persistence of the exchange rate.
} 
adjusting the import share:

$$
\tilde{P}_{m t}(j)=P_{m t}(j)\left[1-\frac{\phi_{m}}{2}\left(\frac{\frac{C_{m t}(j)}{C_{t}}}{\frac{C_{m t-1}(j)}{C_{t-1}}}-1\right)^{2}-\phi_{m} \frac{\frac{C_{m t}(j)}{C_{t}}}{\frac{C_{m t-1}(j)}{C_{t-1}}}\left(\frac{\frac{C_{m t}(j)}{C_{t}}}{\frac{C_{m t-1}(j)}{C_{t-1}}}-1\right)\right]^{-1} .
$$

Also, $\Gamma_{t}$ is a price index consisting of the prices of a firm's competitors and is given by:

$$
\Gamma_{t}=\left[\left(\int_{0}^{1} P_{d t}(i)^{\frac{\gamma}{1-\gamma}} d i\right)^{\frac{\gamma-1}{\gamma-\rho}}+\left(\int_{0}^{\omega} \tilde{P}_{m t}(j)^{\frac{\gamma}{1-\gamma}} d j\right)^{\frac{\gamma-1}{\gamma-\rho}}\right]^{\frac{\gamma-\rho}{\gamma}} .
$$

The ratio of the aggregators of domestic goods to import goods can be expressed in terms of the ratio of two price indices:

$$
\frac{V_{d t}(h)}{V_{m t}(h)}=\left(\frac{\int_{0}^{1} P_{d t}(i)^{\frac{\gamma}{\gamma-1}} d i}{\int_{0}^{\omega} \tilde{P}_{m t}(j)^{\frac{\gamma}{\gamma-1}} d j}\right)^{\frac{\gamma-1}{\gamma-\rho}} .
$$

Expenditure minimization also implies a similar expression for the demand of $C_{d t}(i, h)$ expressed as a function of $\frac{P_{d t}(i)}{\Gamma_{t}}, \frac{V_{m t}(h)}{V_{d t}(h)}$, and $C_{t}(h)$.

We restrict our attention to a symmetric equilibrium in which all households make the same decisions and firms make the same pricing decisions so that $P_{d t}(i)=P_{d t}$ and $P_{m t}(j)=P_{m t}$. In that case, aggregate import demand can be written as $\omega C_{m t}$ where $C_{m t}=C_{m t}(j)$ satisfies:

$$
C_{m t}=\frac{1}{1+\eta}\left[\omega^{\frac{\rho-1}{\gamma-\rho}}\left(\frac{\tilde{P}_{m t}}{\Gamma_{t}}\right)^{\frac{\rho}{\gamma-\rho}}+\eta\right] \frac{C_{t}}{\phi_{m t}} .
$$

In the absence of adjustment costs (i.e., $\phi_{m}=0$ ), aggregate import demand is a combination of a Digit-Stiglitz term and a linear term. If $\eta=0$, then import demand has constant elasticity of substitution (CES) of $\left|\frac{\rho}{\rho-\gamma}\right|$. If $\eta \neq 0$, then the elasticity of substitution is non-constant and depends on $\frac{P_{m t}}{\Gamma_{t}}$. Finally, in a symmetric equilibrium, the price of consumption, $P_{c t}$, is given by:

$$
P_{c t}=P_{d t}\left(\frac{C_{d t}}{C_{t}}\right)+\omega P_{m t}\left(\frac{C_{m t}}{C_{t}}\right)
$$

As discussed above, our aggregator gives rise to a non-constant elasticity of substitution that allows for incomplete pass-through. The fact that the demand curve has a non-constant elasticity of substitution reflects not only that $\eta<0$ but also that there are convex adjustment 
costs for imports specified at the level of the individual good. As a result, even if $\eta=0$, the demand curve would still lead to a non-constant elasticity of substitution that is consistent with incomplete pass-through.

Since we would like to compare scenarios with incomplete pass-through to scenarios with complete pass-through, we need to consider an alternative specification of the adjustment costs. In the complete pass-through scenario, the adjustment costs are specified in terms of household preferences for a final imported good:

$$
\phi_{m t}(h)=1-\frac{\phi_{m}}{2}\left(\frac{\frac{C_{m t}(h)}{C_{t}(h)}}{\frac{C_{m t-1}}{C_{t-1}}}-1\right)^{2}
$$

where $C_{m t}(h)$ is given by:

$$
C_{m t}(h)=\left(\frac{1}{\omega} \int_{0}^{\omega} C_{m t}(j, h)^{\gamma} d j\right)^{\frac{1}{\gamma}} .
$$

We also define a final domestic good as:

$$
C_{d t}(h)=\left(\int_{0}^{1} C_{d t}(j, h)^{\gamma} d i\right)^{\frac{1}{\gamma}} .
$$

In the complete pass-through scenario, $\eta=0$ and the demand aggregator simplifies to:

$$
D\left(\frac{C_{d t}(h)}{C_{t}(h)}, \frac{C_{m t}(h)}{C_{t}(h)}\right)=\frac{1}{\gamma}\left[\left(\frac{C_{d t}(h)}{C_{t}(h)}\right)^{\frac{\gamma}{\rho}}+\omega^{\frac{1}{\rho}}\left(\frac{\phi_{m t}(h) C_{m t}(h)}{C_{t}(h)}\right)^{\frac{\gamma}{\rho}}\right]^{\rho}-\frac{1}{\gamma}+1 .
$$

Thus, with $\eta=0$, it is possible to express the demand aggregator in terms of a final domestic and a final imported good rather than at the individual good level.

With adjustment costs specified at the level of the final imported good and $\eta=0$, the import demand curve for good $\mathrm{j}$ is given by:

$$
C_{m t}(j, h)=\left(\frac{P_{m t}(j)}{P_{m t}}\right)^{\frac{1}{\gamma-1}} \frac{C_{m t}(h)}{\omega},
$$

where $P_{m t}$ is defined as:

$$
P_{m t}=\left(\frac{1}{\omega} \int_{0}^{\omega} P_{m t}(j)^{\frac{\gamma}{\gamma-1}} d j\right)^{\frac{\gamma-1}{\gamma}} .
$$


Importantly, import demand for good $\mathrm{j}$ has a constant elasticity of substitution given by $\left|\frac{1}{\gamma-1}\right|$. However, aggregate import demand $\omega C_{m t}$ will have a non-constant elasticity of substitution due the presence of the adjustment costs, since in a symmetric equilibrium $C_{m t}=C_{m t}(h)$ is given by:

$$
C_{m t}=\omega^{\frac{\rho-1}{\gamma-\rho}}\left(\frac{\tilde{P}_{m t}}{\Gamma_{t}}\right)^{\frac{\rho}{\gamma-\rho}} \frac{C_{t}}{\phi_{m t}}
$$

where the effective price of the final import good is given by:

$$
\tilde{P}_{m t}=P_{m t}\left[1-\frac{\phi_{m}}{2}\left(\frac{\frac{C_{m t}}{C_{t}}}{\frac{C_{m t-1}}{C_{t-1}}}-1\right)^{2}-\phi_{m} \frac{\frac{C_{m t}}{C_{t}}}{\frac{C_{m t-1}}{C_{t-1}}}\left(\frac{\frac{C_{m t}}{C_{t}}}{\frac{C_{m t-1}}{C_{t-1}}}-1\right)\right]^{-1} .
$$

Though the two specifications lead to different import demand schedules for an individual good even if $\eta=0$, the aggregate import demand schedules are quite similar. Comparing equations (B.17) and (B.25), we see that the aggregate import demand schedules are identical when we impose that $\eta=0$ in equation (B.17).

\section{B.3 Firms}

Firms in each country are monopolistically competitive and each firm sells its good to households located in its country. The production function for firm $i$ is linear in labor so that

$$
Y_{t}(i)=N_{t}(i)
$$

A domestic firm hires labor from the economy's representative labor aggregator in a competitive market. Labor is assumed to be completely mobile within a country but immobile across countries. Marginal cost is therefore the same for all firms in the home country and is the equal to the home economy's nominal wage $W_{t}$.

To introduce sticky prices in our setup, we assume that firm $i$ faces a cost of adjusting its domestic price:

$$
\phi_{d t}(i)=\frac{\phi_{d}}{2}\left(\frac{\frac{P_{d t}(i)}{P_{d t-1}(i)}}{\frac{P_{d t-1}}{P_{d t-2}}}-1\right)^{2} .
$$


As was the case for wages above, price adjustment costs are related to changes in a firm's inflation rate relative to the past inflation rate for the entire economy. A firm maximizes its expected discounted stream of profits in the domestic market:

$$
E_{t} \sum_{j=0}^{\infty} \xi_{t, t+j}\left\{\left[P_{d t+j}(i)-W_{t+j}\right] C_{d t+j}(i)\left[1-\phi_{d t+j}(i)\right]\right\}
$$

by choosing contingency plans for $\left\{P_{d t+j}(i), C_{d t+j}(i)\right\}_{j=0}^{\infty}$ and taking the nominal wage and the household demand schedule in the domestic market as given.

As discussed above, the demand schedule for an individual good differs across the scenarios with complete and incomplete pass-through. In the incomplete pass-through scenarios, the demand aggregator involves adjustment costs on imports at the individual good level and $\eta<0$. In this case, the demand schedule for good $i$ is:

$$
C_{d t}(i)=\frac{1}{1+\eta}\left[\left(\frac{P_{d t}(i)}{\Gamma_{t}}\right)^{\frac{1}{\gamma-1}}\left(1+\frac{V_{m t}}{V_{d t}}\right)^{\frac{1-\rho}{\gamma-1}}+\eta\right] C_{t} .
$$

In contrast, in the complete pass-through scenario, the adjustment costs are specified at the aggregate level and $\eta=0$ so that the demand for good $i$ is:

$$
C_{d t}(i)=\left(\frac{P_{d t}(i)}{P_{d t}}\right)^{\frac{1}{\gamma-1}} C_{d t}
$$

where $P_{d t}$ is given by an analogous expression to the definition of $P_{m t}$ in equation (B.24). An implication of these different specifications is that the incomplete pass-through scenario will be associated with more nominal price inertia and output persistence due to the strategic complementarity in price-setting that arises when $\eta<0 .{ }^{31}$

While all domestic firms sell their goods to domestic households, only a subset of these firms sell their goods to households abroad. Specifically, firms indexed by $i \in\left[0, \omega^{*}\right]$, where

\footnotetext{
${ }^{31}$ We follow Woodford (2003) and define pricing decisions to be strategic complements if an increase in the prices charged for other goods increases a firm's own optimal price. For a similar approach to modeling the strategic complementarity in an open economy, see Bergin and Feenstra (2001). The strategic complementarity in price setting also arises in models with monopolistic competition and distribution services such as Corsetti and Dedola (2005) and Corsetti, Dedola, and Leduc (2005). In these models, an increase in the price of nontradeables induces a firm in the tradeable sector to increase its price. For a game-theoretic approach, see, for example, Atkeson and Burnstein (2005) or Bodnar, Dumas, and Marston (2002).
} 
$\omega^{*}$ denotes the home-bias parameter of the foreign country, sell their goods both in the home and foreign country. (We use an asterisk to denote a variable in the foreign country). The remaining fraction of firms sell their goods only in the home market.

We assume that a firm can charge a different price for its good at home and abroad, and as in Betts and Devereaux (1996), firms practice local currency pricing. More specifically, a domestic firm faces a cost of adjusting its export price denominated in units of foreign currency:

$$
\phi_{x t}(i)=\frac{\phi_{x}}{2}\left(\frac{\frac{P_{m t}^{*}(i)}{P_{m t-1}^{*}(i)}}{\frac{P_{m t-1}^{*}}{P_{m t-2}^{*}}}-1\right)^{2} .
$$

When $\phi_{x}>0$, there is nominal inertia in an exporter's price denominated in foreign currency and pass-through of exchange-rate changes to foreign import prices will be incomplete. In the scenario in which import pass-through is incomplete, we allow for $\phi_{x}>0$, while in the complete pass-through scenario, we set $\phi_{x}=0$.

A firm that sells its good abroad maximizes its expected discounted stream of profits in the foreign market:

$$
E_{t} \sum_{j=0}^{\infty} \xi_{t, t+j}\left\{\left[e_{t+j} P_{m t+j}^{*}(i)-W_{t+j}\right] C_{m t+j}^{*}(i)\left[1-\phi_{x t+j}(i)\right]\right\},
$$

by choosing contingency plans for $\left\{P_{m t+j}^{*}(i), C_{m t+j}^{*}(i)\right\}_{j=0}^{\infty}$ and taking the nominal wage and demand schedule of foreign households as given. In the complete pass-through scenario in which $\eta^{*}=0$ and the adjustment costs are specified at the level of the final imported good, the demand schedule for foreign households is given by the foreign equivalent to equation (B.23). In the incomplete pass-through scenario, the foreign household demand schedule for good $i$ is given by

$$
C_{m t}^{*}(i)=\frac{1}{1+\eta^{*}}\left[\left(\frac{\tilde{P}_{m t}^{*}(i)}{\Gamma_{t}^{*}}\right)^{\frac{1}{\gamma^{*}-1}}\left(1+\frac{V_{d t}^{*}}{V_{m t}^{*}}\right)^{\frac{1-\rho^{*}}{\gamma^{*}-1}}+\eta^{*}\right] \frac{C_{t}^{*}}{\phi_{m t}^{*}(i)},
$$

where $\phi_{m t}^{*}(i)$ represents the adjustment costs paid by foreign households for good $i$ (equation B.19), and $\tilde{P}_{m t}^{*}(i)$ is the effective price of good $i$ inclusive of these adjustment costs (equation B.14). 
To better understand the role of our demand aggregator in accounting for incomplete pass-through, it is instructive to abstract from the adjustment costs on the imported good and on a firm's export price (i.e., $\phi_{m}^{*}=0$ and $\phi_{x}=0$ ). In this case, exporter $i$ chooses its export price as a markup over marginal cost, $W_{t}$. In a symmetric equilibrium all domestic exporters choose the same price so that $P_{m t}^{*}(i)=P_{m t}$ and the export price relationship is:

$$
P_{m t}^{*}=\mu_{m t}^{*} \frac{W_{t}}{e_{t}}
$$

where the markup $\mu_{m t}^{*}$ can be expressed as:

$$
\mu_{m t}^{*}=\left[1-\frac{1}{\left|\epsilon_{m t}^{*}\right|}\right]^{-1}=\left[\gamma^{*}+\eta^{*}\left(\gamma^{*}-1\right)\left(\omega^{*}\right)^{\frac{1-\rho^{*}}{\gamma^{*}-\rho^{*}}}\left(\frac{P_{m t}^{*}}{\Gamma_{t}^{*}}\right)^{\frac{\rho^{*}}{\rho^{*}-\gamma^{*}}}\right]^{-1}
$$

and the demand elasticity $\left|\epsilon_{m t}^{*}\right|$ is given by:

$$
\left|\epsilon_{m t}^{*}\right|=\left[\left(1-\gamma^{*}\right)\left(1+\eta^{*}\left(\omega^{*}\right)^{\frac{1-\rho^{*}}{\gamma^{*}-\rho^{*}}}\left(\frac{P_{m t}^{*}}{\Gamma_{t}^{*}}\right)^{\frac{\rho^{*}}{\rho^{*}-\gamma^{*}}}\right)\right]^{-1} .
$$

Equation (B.35) shows that a firm's pricing decision depends not only on its marginal cost (denominated in foreign currency) but also on $\Gamma_{t}^{*}$, the prices of its competitors in the foreign market. We calibrate our demand aggregator to allow for strategic complementarity in price setting by choosing parameters that satisfy $\frac{\eta^{*} \rho^{*}\left(1-\gamma^{*}\right)}{\rho^{*}-\gamma^{*}}<0$. In that case, $\left|\epsilon_{m t}^{*}\right|$ is an increasing function of $\frac{P_{m t}^{*}}{\Gamma_{t}^{*}}$ and a firm's desired markup will be a decreasing function of this relative price. As a consequence, a domestic exporter will find it desirable to lower its markup in response to a shock that raises its costs relative to its competitors, because the exporter does not want its price to deviate too far from its competitors' prices. In this way, pass-through of exchange-rate changes to import prices can be incomplete even in the absence of nominal price rigidities. In contrast, in the complete pass-through scenario, the elasticity of substitution, $\left|\epsilon_{m t}^{*}\right|$, is equal to the constant $\frac{1}{1-\gamma^{*}}$ and the desired markup does not vary.

\section{B.4 Monetary Policy and Resource Constraint}

We assume that monetary policy follows an interest rate rule:

$$
\hat{i}_{t}=\gamma_{\pi} \hat{\pi}_{c t}+\gamma_{y} \hat{y}_{t}
$$


where the symbol “^, denotes the logarithmic deviation of a variable from its steady state value. Hence, $\hat{i}_{t}$ denotes the (gross) quarterly nominal interest rate expressed as a log-deviation from steady state, $\pi_{c t}=\frac{P_{c t}}{P_{c t-1}}$ is the quarterly rate of consumer price inflation, and $y_{t}$ is aggregate output in the domestic economy. Domestic output is determined from the economy's resource constraint:

$$
y_{t}=\int_{0}^{1} y_{t}(i) d i=C_{d t}\left(1-\phi_{d t}\right)+\omega^{*} C_{m t}^{*}\left(1-\phi_{x t}\right) .
$$

The evolution of net foreign assets can be expressed as:

$$
\frac{e_{t} P_{B t}^{*} B_{F t+1}}{\phi_{b t}}-e_{t} B_{F t}=\left(\omega^{*} e_{t} P_{m t}^{*} C_{m t}^{*}-\omega P_{m t} C_{m t}\right)-\phi_{w t} W_{t} L_{t}-\phi_{d t} P_{d t} C_{d t}-\phi_{x t} e_{t} P_{m t}^{*} C_{m t}^{*} .
$$

In this expression, the term in parenthesis is the nominal trade balance, while the remaining terms on the right hand side of the equality reflect the costs to adjusting nominal prices and wages. $^{32}$

\section{B.5 Solution Method and Calibration}

We solve the model by log-linearizing the equations around the steady state. To obtain the reduced-form solution of the model, we use the numerical algorithm of Anderson and Moore (1985), which provides an efficient implementation of the method proposed by Blanchard and Kahn (1980) (see also Anderson (1997)).

In order to investigate the implications of the decline in pass-through for the trade balance, we consider three alternative calibrations of the parameters governing the demand aggregator. For our first scenario in which import price pass-through is high in both the home and foreign economies, we set $\eta=\eta^{*}=0$ so that the aggregator has a constant elasticity of substitution and used the import adjustment costs specified at the aggregate level. Also, we set $\rho=\rho^{*}=25$ and $\gamma=\gamma^{*}=0.8$. These values imply that the markup of domestic firms in

\footnotetext{
${ }^{32}$ This expression can be derived from the household budget constraint after imposing that domestic bonds are in zero net supply, the definition of firm profits, the resource constraint, and using expression (B.18) which defines the consumer price level.
} 
the home market is 25 percent, and the trade-price elasticity of imports is slightly larger than unity in the long run. We also set $\phi_{x}=\phi_{x}^{*}=0$ so that nominal export prices are completely flexible.

In the second scenario in which import price pass-through is low in both economies, we used the import adjustment costs specified at the individual good level and set $\eta=\eta^{*}=-3$, $\rho=\rho^{*}=0.4$, and $\gamma=\gamma^{*}=1.08$. These values imply a domestic markup for domestic firms of 28 percent and a long-run trade-price elasticity of about one. In this case, we set $\phi_{x}$ and $\phi_{x}^{*}$ to be consistent with price contracts for export prices that last for two quarters and are subject to lagged indexation.

In the third scenario, in which import price pass-through is low in the home country and high abroad, we set the demand curve parameters for the home country and adjustment cost parameter for foreign export prices to those used in the second scenario and those parameters for the foreign country equal to their values in the first scenario.

In all three of these scenarios, we choose $\omega$ and $\omega^{*}$ so that in steady state the ratio of nominal imports to nominal GDP is 12.5 percent in both economies. Given that trade is balanced in steady state, the export shares in both economies is also 12.5 percent. Finally, in all three scenarios, we normalized the steady state level of hours worked so that $L=L^{*}=1$ by appropriate choice of $\chi_{0}$ and $\chi_{0}^{*}$.

The remainder of the parameters were chosen to be the same across the two economies. ${ }^{33}$ We set $\beta=1.03^{-0.25}$ and calibrated the model at a quarterly frequency. The utility function parameter $\chi=1.5$, which implies a Frisch elasticity of labor supply of $2 / 3$. We set $\gamma_{w}=$ 0.8 which is consistent with a wage markup of 25 percent. We choose the adjustment costs parameters for wages and domestic prices to be consistent with four-quarter contracts. For the adjustment cost parameter on imports, we set $\phi_{m}=2$, which in all three scenarios implies that the trade-price elasticity in the period of a shock is about 0.3 . We choose a small value for the financial intermediation cost $\left(\phi_{b}=0.0001\right)$, which is necessary to ensure that the model has a unique steady state. For the monetary policy rule, we follow Taylor (1993) and set $\gamma_{\pi}=1.5$

\footnotetext{
${ }^{33}$ In the first and second scenarios, the home and foreign economy are identical, and all of the model's parameters for the foreign economy are the same as those of the home economy.
} 
and $\gamma_{y}=\frac{0.5}{4}$.

Finally, we specified the following $A R(1)$ process for the risk premium shock:

$$
\nu_{b t}=\rho_{\nu_{b}} \nu_{b t-1}+\sigma_{\nu_{b}} \epsilon_{\nu_{b}} .
$$

We set $\rho_{\nu_{b}}=0.98$ and choose $\sigma_{\nu_{b}}$ so that the real exchange rate, $q_{t}=\frac{e_{t} P_{d t}^{*}}{P_{d t}}$, depreciates 10 percent in the third scenario in the period of the shock. 
Figure 1: Home Economy

(Deviation from Steady State)
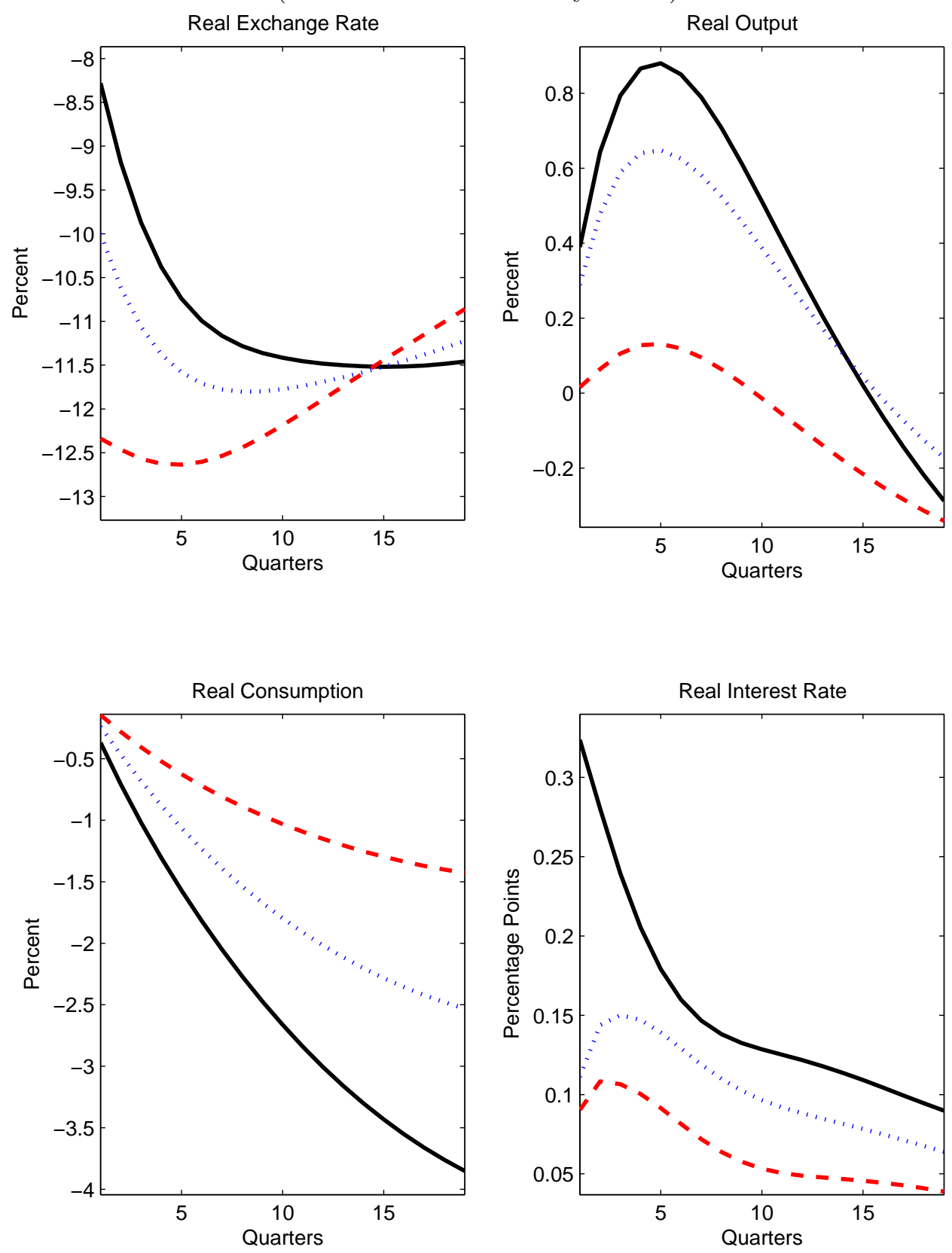

Scenario 1: High Import Price PT (Both Countries)

Scenario 2: Low Import Price PT (Both Countries) Scenario 3: Low Import Price PT (Home Only) 
Figure 2: Home Imports

(Deviation from Steady State)
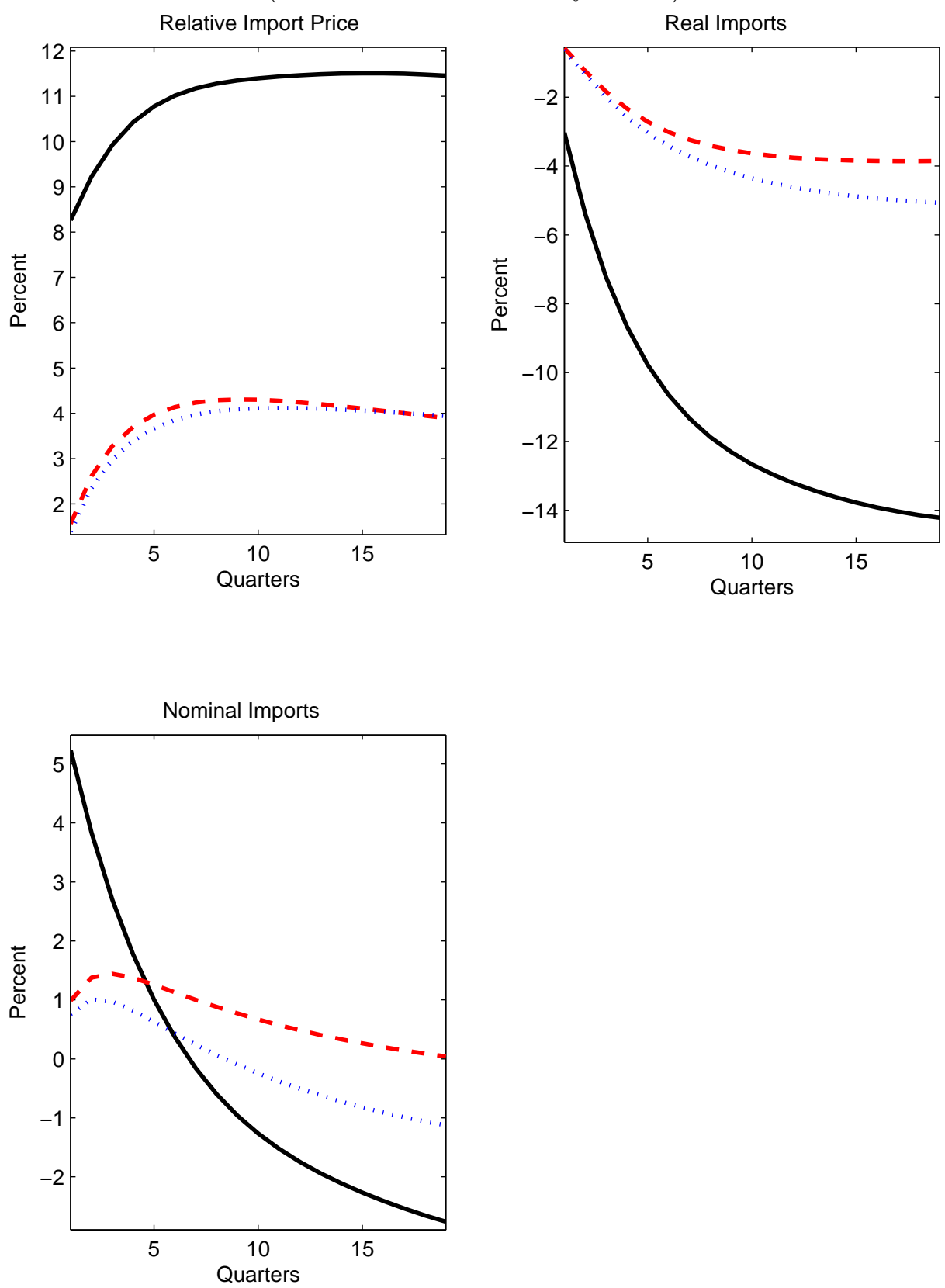

Scenario 1: High Import Price PT (Both Countries)

- Scenario 2: Low Import Price PT (Both Countries) Scenario 3: Low Import Price PT (Home Only) 
Figure 3: Home Exports

(Deviation from Steady State)
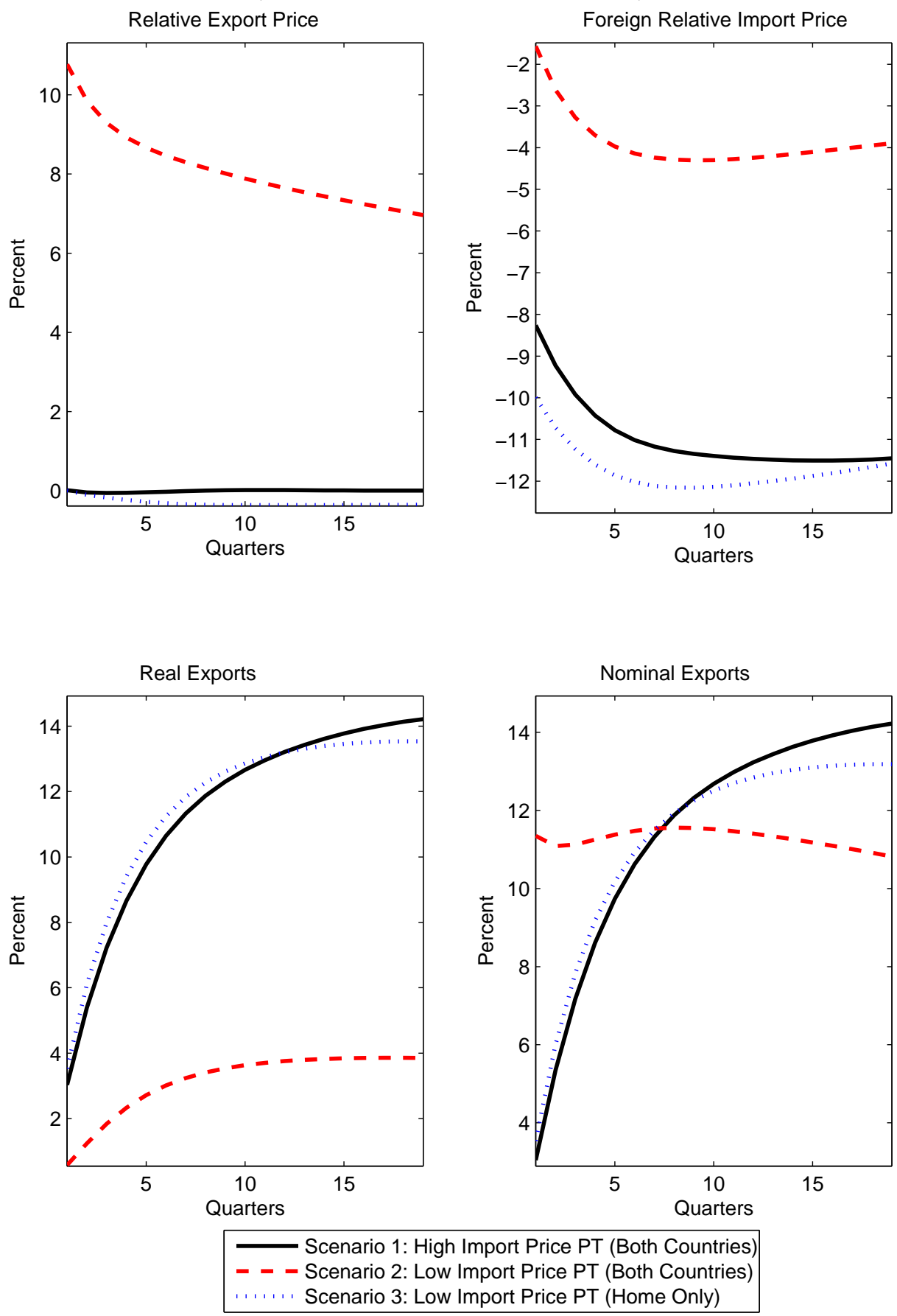
Figure 4: Home Trade Balance

(Deviation from Steady State)
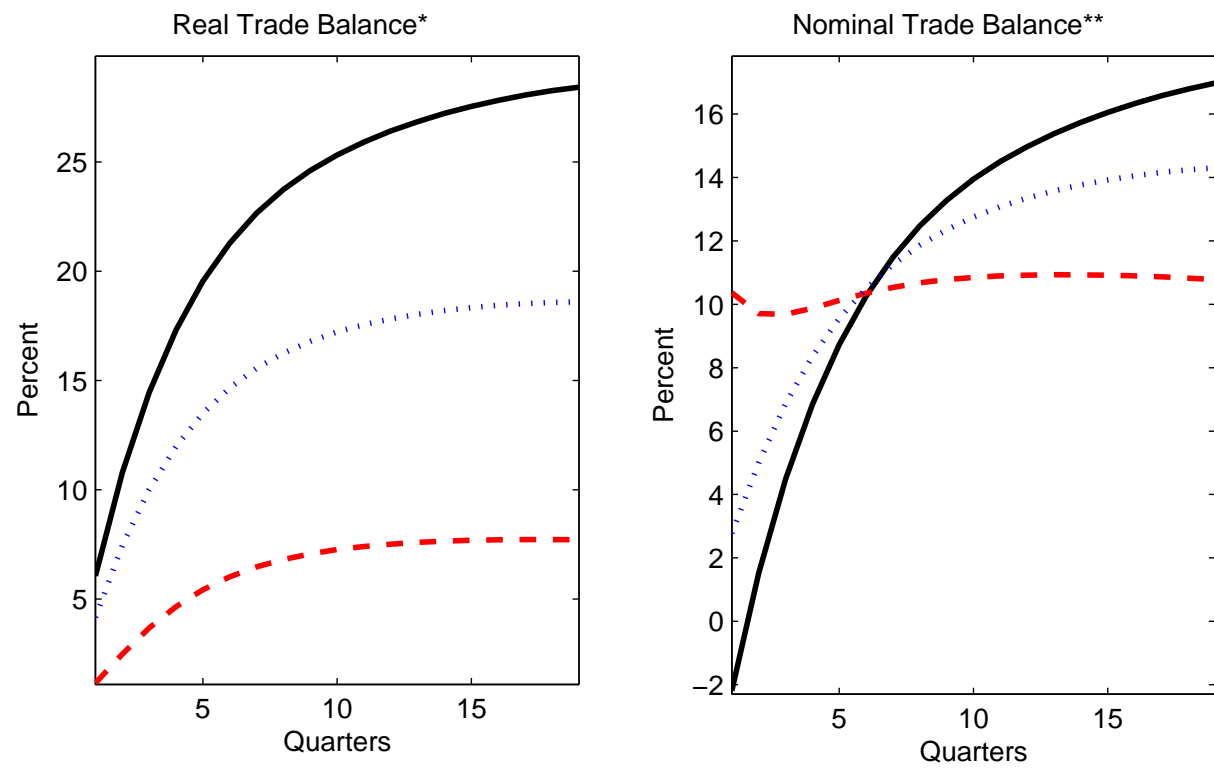

${ }^{*}$ Ratio of real exports to imports.

${ }^{\star *}$ Ratio of nominal exports to nominal imports.
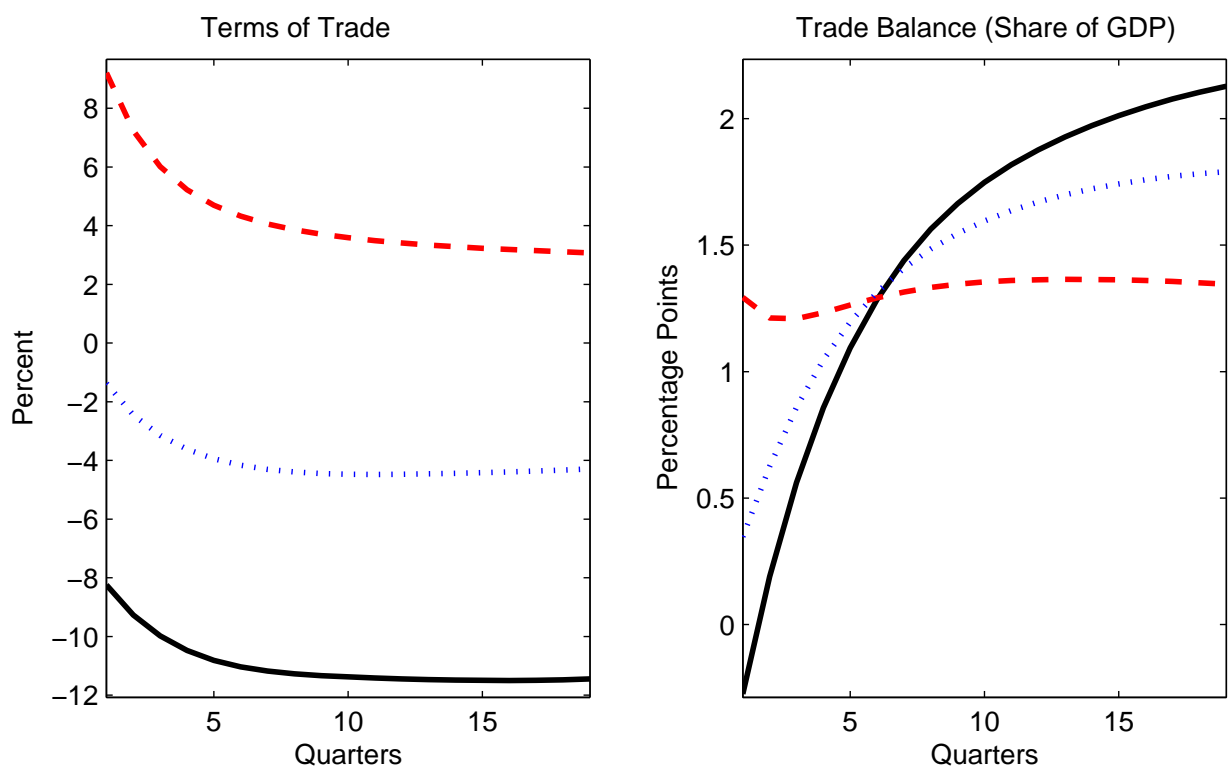

Scenario 1: High Import Price PT (Both Countries)

- - - Scenario 2: Low Import Price PT (Both Countries) Scenario 3: Low Import Price PT (Home Only) 
Figure 5: Foreign Economy

(Deviation from Steady State)
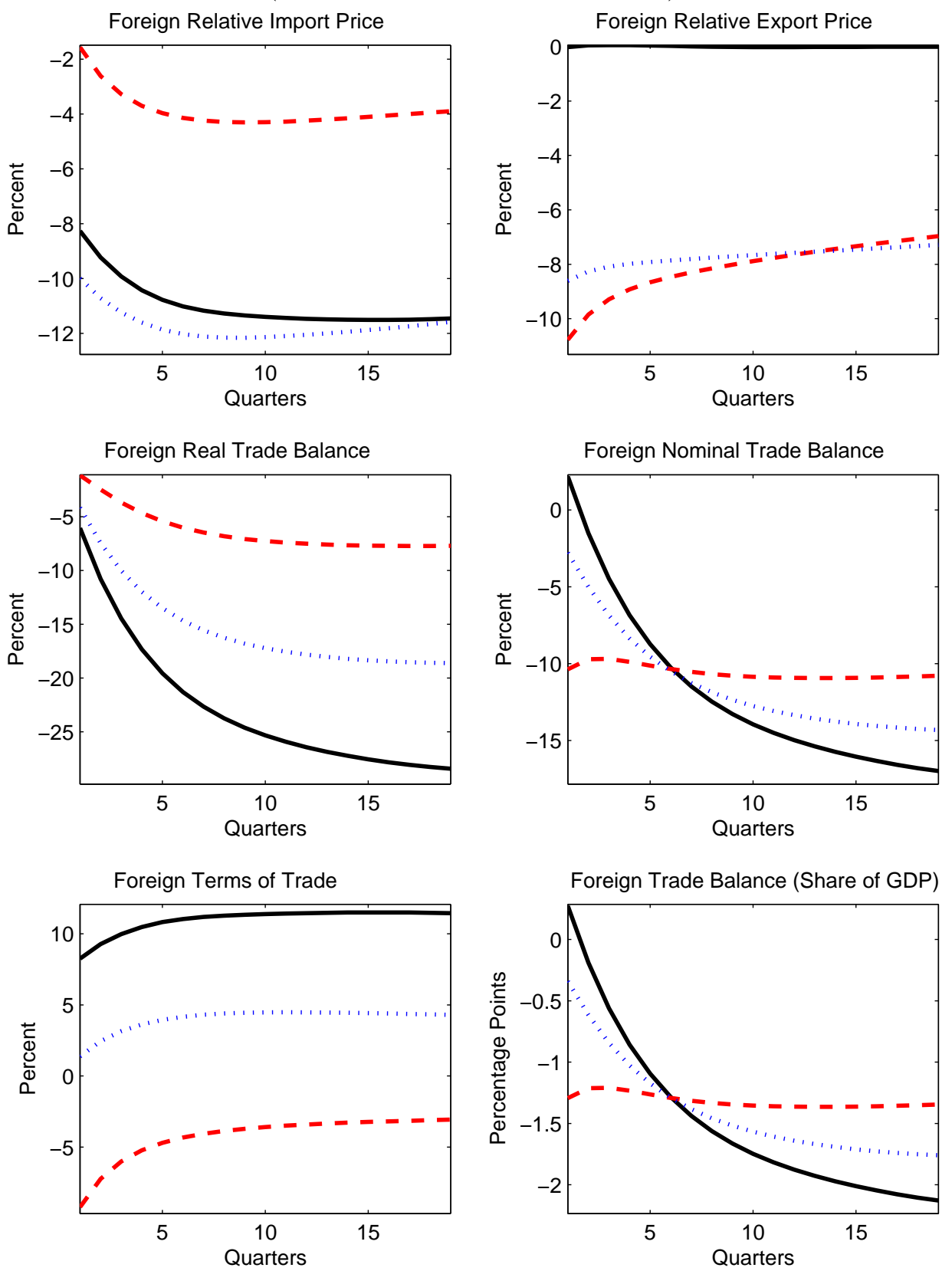

- Scenario 1: High Import Price PT (Both Countries)

- - - Scenario 2: Low Import Price PT (Both Countries) ....... Scenario 3: Low Import Price PT (Home Only) 